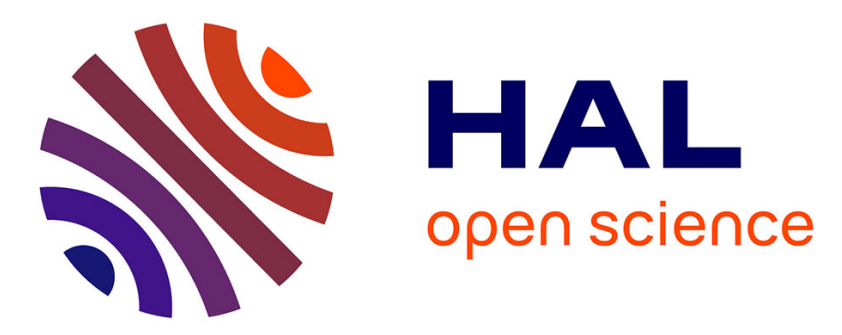

\title{
Explosive activity of the summit cone of Piton de la Fournaise volcano (La Réunion island): A historical and geological review
}

Laurent Michon, Andrea Di Muro, Nicolas Villeneuve, Cécile Saint-Marc, Pierluigi Fadda, Fabio Manta

\section{To cite this version:}

Laurent Michon, Andrea Di Muro, Nicolas Villeneuve, Cécile Saint-Marc, Pierluigi Fadda, et al.. Explosive activity of the summit cone of Piton de la Fournaise volcano (La Réunion island): A historical and geological review. Journal of Volcanology and Geothermal Research, 2013, 264, pp.117133. 10.1016/j.jvolgeores.2013.06.012 . hal-01148217

\section{HAL Id: hal-01148217 https://hal.science/hal-01148217}

Submitted on 24 Oct 2016

HAL is a multi-disciplinary open access archive for the deposit and dissemination of scientific research documents, whether they are published or not. The documents may come from teaching and research institutions in France or abroad, or from public or private research centers.
L'archive ouverte pluridisciplinaire HAL, est destinée au dépôt et à la diffusion de documents scientifiques de niveau recherche, publiés ou non, émanant des établissements d'enseignement et de recherche français ou étrangers, des laboratoires publics ou privés. 


\title{
Explosive activity of the summit cone of Piton de la Fournaise volcano (La Réunion island): A historical and geological review
}

\author{
Laurent Michon $^{\mathrm{a}, *}$, Andrea Di Muro ${ }^{\mathrm{b}}$, Nicolas Villeneuve ${ }^{\mathrm{a}, \mathrm{b}}$, Cécile Saint-Marc ${ }^{\mathrm{c}}$, Pierluigi Fadda ${ }^{\mathrm{b}}$, Fabio Manta ${ }^{\mathrm{b}}$ \\ a Laboratoire Géosciences Réunion, Université de La Réunion, Institut de Physique du Globe de Paris, Sorbonne Paris-Cité, UMR 7154 CNRS, F-97715 Saint-Denis, France \\ b Observatoire Volcanologique du Piton de la Fournaise (OVPF), Institut de Physique du Globe de Paris, Sorbonne Paris-Cité, UMR 7154 CNRS, Université Paris Diderot, F-75238 Paris, France \\ c LIG - Equipe STEAMER, Bat ENSIMAG - D 314, 681 Rue de la passerelle, 38400 Saint-Martin-d'Hères, France
}

\begin{abstract}
A B S T R A C T
Summit explosive activity and collapses that form pit craters and calderas represent major volcanic hazards on a dominantly effusive, frequently active volcano like Piton de la Fournaise. Only three summit collapse events $(1986,2002,2007)$ have been recorded since the foundation of the Piton de la Fournaise volcano observatory (OVPF) in 1979, and two of them (1986 and 2007) were associated with weak phreatic activity. At Piton de la Fournaise, the normal explosive activity consists of short-lived and mild ( $<20 \mathrm{~m}$-high) lava fountains, which quickly evolve into strombolian activity during the eruptions. Based on comprehensive literature review and high-resolution image analysis of surface outcrops and summit caldera walls, we reconstructed the time distribution of recent explosive events (phreatomagmatic; phreatic) and their link with summit collapses and lateral (flank) effusive eruptions. In historical time (post-1640 CE), we recognise two main clusters of explosive events. Frequent and violent phreatomagmatic to phreatic explosions occurred during the oldest cluster (1708-1878) and alternated with long-lasting periods (years to decades) of summit effusive activity. In contrast, scarce, and on average, weak explosions occurred during the youngest cluster (1897-2012), when discrete and short-lived ( $<6$ months) effusive eruptions represent the main eruptive dynamics. Historical summit collapses (pit craters and caldera), all localised at the top of the summit cone, were related to voluminous lateral eruptions and were followed by a significant decrease in eruptive rate. However, magma draining during lateral eruptions was not systematically associated with summit collapses or explosions. The long-lasting occurrence of magma at very shallow depth below the volcano summit, followed by a rapid lateral drainage, apparently represents a critical condition favouring magma-groundwater interaction to produce explosive activity. The prehistoric growth of the Piton de la Fournaise summit cone results chiefly from long-lasting to continuous activity, centred below its westem side (Bory crater containing lava lakes). High lava fountains, long-lasting effusive activity, lava lakes, ash plumes and block ejections were common types of eruptive dynamics in the historical past, between 1640 and 1878. In this perspective, short-lived, small volume eruptions and long pauses, up to six years, during the last century of activity of Piton de la Fournaise can be considered as a lull, despite the high frequency of eruption ( 1 eruption/9 months on average). Temporal and spatial variations in recurrence rate and eruptive dynamics of basaltic volcanism, such as those recognised at Piton de la Fournaise, should be considered in the formulation of hazard assessments and in the interpretation of precursory patterns.
\end{abstract}

Contents

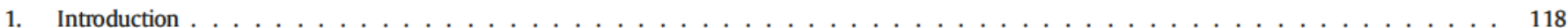

2. Data and methods . . . . . . . . . . . . . . . . . . . . . . . . . . . . . . . . . . 119

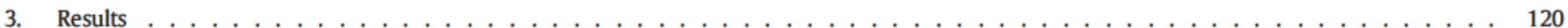

3.1. Historical summit activity . . . . . . . . . . . . . . . . . . . . . . . . . . . . . . . . . . 120

3.2. Dynamics and deposits of the summit explosive events . . . . . . . . . . . . . . . . . . . . . . . . . . 122

3.2.1. Recent collapses and explosive activity (post-1900) $\ldots \ldots \ldots \ldots \ldots \ldots$

3.2.2. Historical collapses and explosive eruptions $($ pre-1900 $) \ldots \ldots \ldots \ldots$

\footnotetext{
* Corresponding author.

E-mail address: laurent.michon@univ-reunion.fr (L. Michon).
} 


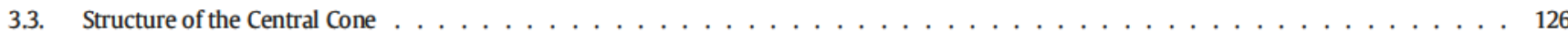

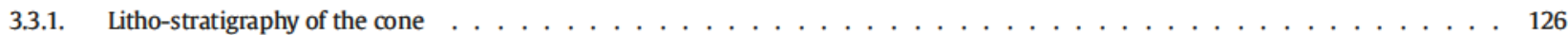

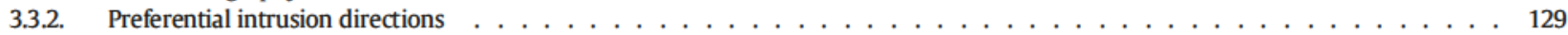

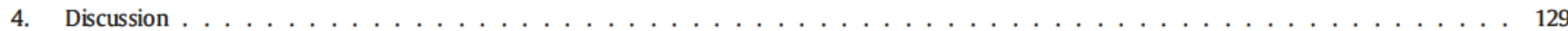

4.1. Age and dynamics of the Central Cone . . . . . . . . . . . . . . . . . . . . . . . . . . . . . . . . . . . . . . 129

4.2. General Implications for the eruptive dynamics of Piton de la Foumaise . . . . . . . . . . . . . . . . . . . . . . . . . . . . 130

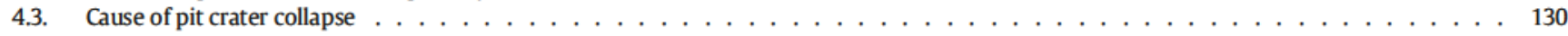

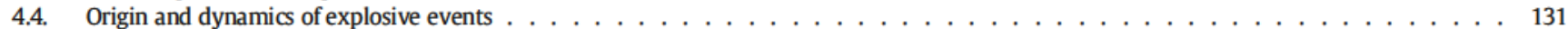

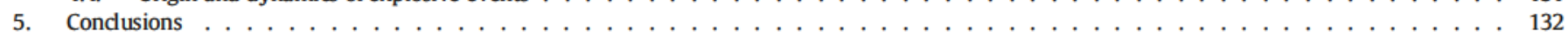

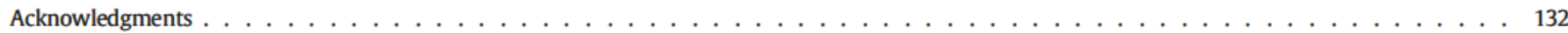

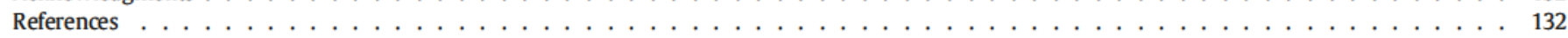

\section{Introduction}

Forecasts of volcanic hazard and assessment of related risks produced by a given volcanic system require detailed knowledge of its variability (in space and time) in terms of eruptive dynamics. At Piton de la Fournaise, the active volcano of La Réunion hotspot, the volcanic activity is dominantly effusive and eruptive vents and fractures occur scattered on the whole massif (Villeneuve and Bachèlery, 2006). The eruptive activity has relatively long return times on the volcano flanks, i.e. decades on the southeast and northeast flanks and centuries on the western flank, whereas the eruptive frequency markedly increases when moving closer to the Central Cone (Fig. 1). The average frequency of central activity is 1 eruption every 9 months, with rare long-lasting pauses ( 6 years at maximum; Roult et al., 2012 and references therein).

Three volcanic scenarios have classically been outlined for Piton de la Fournaise.

In the first, the magma ascends below the Central Cone (Lénat and Bachèlery, 1990; Roult et al., 2012) and, in some cases, laterally propagates at shallow level. Lateral dike propagation along the northeast and southeast rift zones outside the Enclos Fouqué caldera is the main
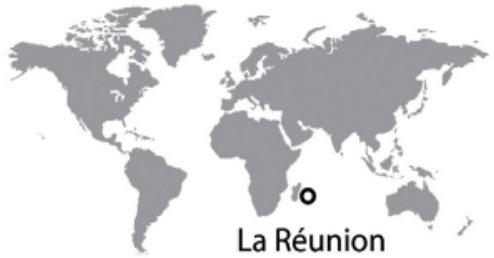

Island

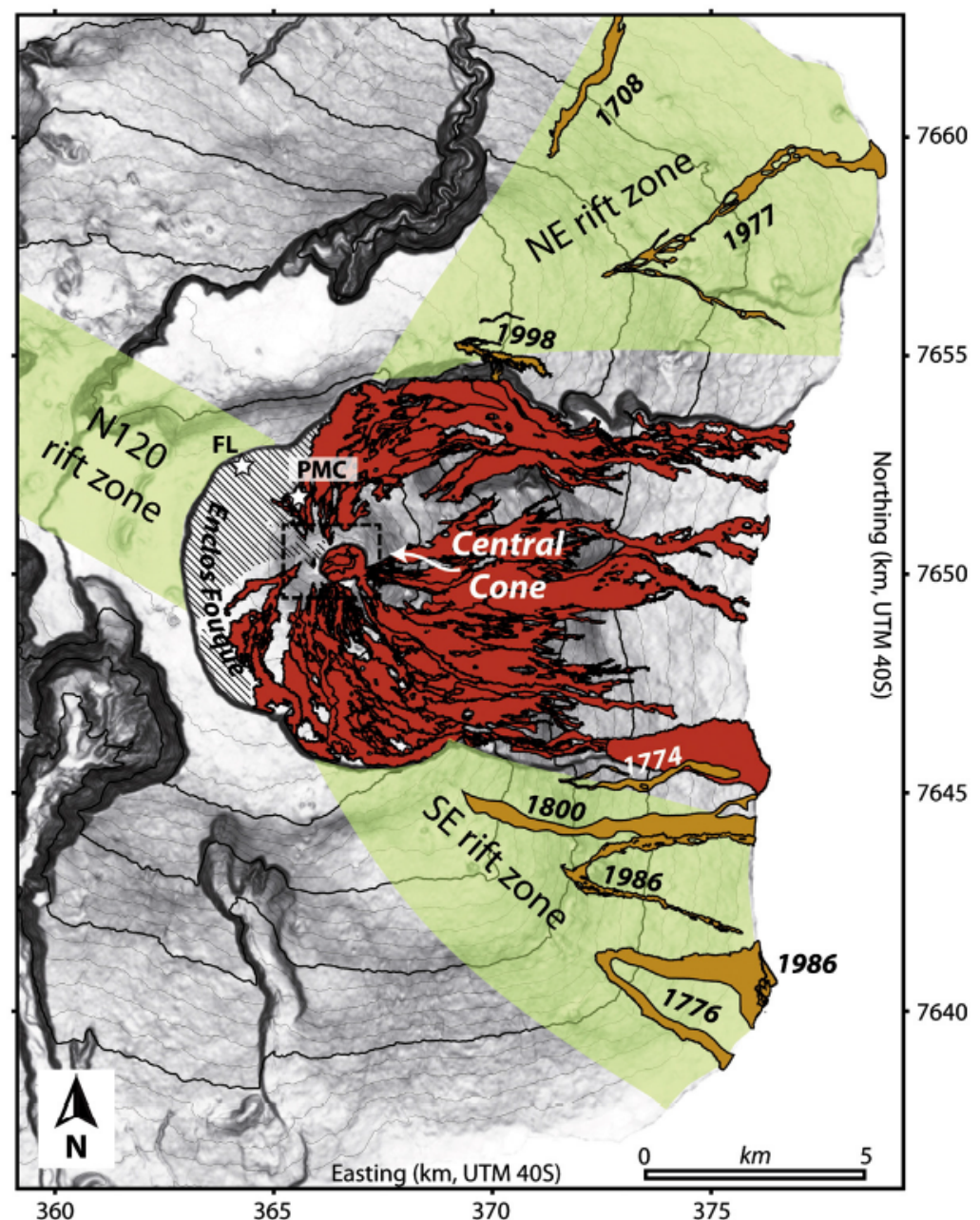

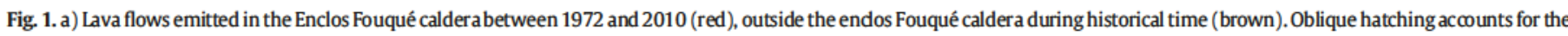

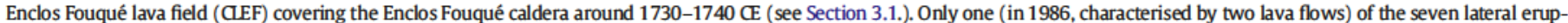

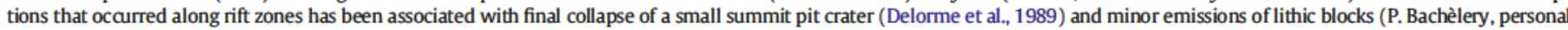

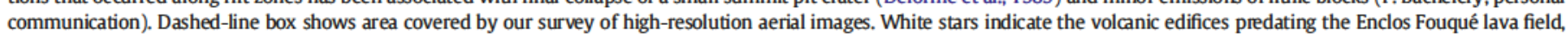
i.e. the Formica Leo FL and Puy Mi-Côte PMC cones. 
known process able to periodically affect remote and inhabited sectors of the volcano (Fig. 1; Villeneuve and Bachèlery, 2006). Since 1900, this central activity has been characterised by episodic effusive eruptions (lasting 0.3 days to 6.5 months), having a small to moderate volume $\left(0.1-240 \mathrm{Mm}^{3}\right)$ and only rare and, in most cases, weak ash plumes (Villeneuve and Bachèlery, 2006; Roult et al., 2012).

In the second scenario, lateral (flank) eruptions and intrusions may culminate in summit collapses of small pit craters (e.g., 1953, 1986, 2002; Ducrot, 1958; Hirn et al., 1991; Longpré et al., 2007) or larger calderas (1931; 2007; Michon et al., 2007; Roult et al., 2012). Rare summit explosive events have been reported in historical times (Villeneuve and Bachèlery, 2006). The link between lateral effusive activity, summit collapses and explosive activity is, however, far from being systematic, and its study represents one of the main targets of our paper.

The third scenario contrasts with the others and is represented by a decades-long phase of continuous lava effusion in the 18th century that produced long-lasting lava flows that formed the Enclos Fouqué pāhoehoe field (Lénat et al., 2001).

In all three scenarios, the eruptive dynamics is mainly effusive or weakly explosive (strombolian, small Hawaiian fountains $<20 \mathrm{~m}$ high, rarely attaining $100-200 \mathrm{~m}$ in height; Staudacher et al., 2009). Such activity is consistent with the relatively low dissolved volatile content in basaltic magma of Piton de la Fournaise $\left(\mathrm{H}_{2} \mathrm{O}<1.6 \mathrm{wt} . \%\right.$ and generally < 0.9 wt.\%; Bureau et al., 1998, 1999). Yet the widespread occurrence of many ballistic blocks scattered on the ground around the summit craters unambiguously shows that important explosive events affected the summit area in the past. Little is known, however, about their age and the volcanic scenario they are associated with.

It is thus important to address the relationship between effusive activity, dynamics of summit collapses (timing and volume) and block and ash emissions, as these events represent the most hazardous phenomena for the visitors accessing the summit area (up to 1000 tourists/day) and the associated fine ash has potential regional impact. In such a context, the identification and characterization of phreatic or phreatomagmatic events is of paramount importance for a complete assessment of volcanic hazard at Piton de la Fournaise.

Here we combine 1) a detailed review of historical reports (post $1700 \mathrm{CE}$ ) with 2) an unprecedented high-resolution photographic anal$y$ sis of i) the surface of the summit and of ii) the inner walls of Dolomieu summit caldera, exposed after the 2007 summit collapse. Our study offers, for the first time, a complete review and characterization of the main deviations from typical effusive activity for Piton de la Fournaise volcano.

\section{Data and methods}

Several partial reviews of the historical summit activity have been published (e.g., Bachèlery, 1981; Lénat et al., 2001; Carter et al., 2007; Peltier et al., 2012). However, these authors based their work on two main syntheses (Bory de Saint Vincent, 1804; Lacroix, 1936), which contain significant contradictions with respect to the original reports they refer to. We consequently reviewed the original texts describing the evolution of the historical summit activity (Table 1 ).

The characterization of the summit explosive eruptions has been obtained by combining i) photographic reports of the 1961 and 2007 explosive events, with ii) the analysis of the rare preserved deposits around the summit craters and iii) detailed mapping of the lithic blocks from a set of high-resolution, orthorectified, georeferenced aerial photographs (10-cm-wide pixels; Fig. 2a). The mean diameter MD of each lithic block observed in the photos was calculated on the basis of

Table 1

Summit observations between 1751 and 1930.

\begin{tabular}{|c|c|c|c|}
\hline Historical reports & Date of observation & Description & Pages \\
\hline \multirow[t]{2}{*}{ Dolnet de Palmaroux in d'Heguerty (1755) } & \multirow[t]{2}{*}{ September 21,1751} & No summit eruption & 225 \\
\hline & & Blinding lava flows in the Endos Fouqué caldera & 226 \\
\hline de Crémont (1770) & October 27,1768 & $\begin{array}{l}\text { Summit eruption with ballistics and black plumes above a steep cone } \\
\text { (subsequently named Mamelon Central) }\end{array}$ & $87-91$ \\
\hline \multirow[t]{2}{*}{ Commerson in de Montessus (1889) } & \multirow[t]{2}{*}{1770} & Summit eruption with ballistics from a steep cone (subsequently named Mamelon Central) & 154 \\
\hline & & 300 paces between the active cone and an inactive crater (subsequently named Bory) & 154 \\
\hline \multirow[t]{3}{*}{ Bert in Bory de Saint Vinœnt (1804) } & July 17 (14?), 1791 & Dense dark and white plume above the summit coeval with the large June-July eruption. & 284-285 \\
\hline & \multirow[t]{2}{*}{ July $22-23,1791$} & $\begin{array}{l}\text { High lava fountains in a new vent located south of the summit } \\
\text { (subsequently named Dolomieu) }\end{array}$ & $284-285$ \\
\hline & & Inactive truncated cone (subsequently named Mamelon Central) & 285 \\
\hline \multirow[t]{3}{*}{ Bert in Lacroix (1936) } & \multirow[t]{3}{*}{ October 23, 1791} & Inactive crater in the west (subsequently named Bory) & 39 \\
\hline & & Inactive cone with fumaroles $\sim 350$ m east of the inactive crater (Mamelon Central) & 40 \\
\hline & & $\begin{array}{l}\text { New pit crater formed on July } 17 \text { (14?) } 1791 \text { south of the inactive cone } \\
\text { (subsequently named Dolomieu) }\end{array}$ & 40 \\
\hline \multirow[t]{5}{*}{ Bory de Saint Vincent (1804) } & \multirow[t]{5}{*}{ October-November, 1801} & Inactive crater in the west named Bory by Juvencourt & 237 \\
\hline & & Inactive cone named Mamelon Central by Bory de Saint Vincent & 231 \\
\hline & & New pit crater named Dolomieu by Bory de Saint Vinœnt & 234 \\
\hline & & $\begin{array}{l}\text { Lava fountain inside Dolomieu and lava flow emitted from an eruptive fissure on the } \\
\text { SE flank of the Central Cone }\end{array}$ & $233-234$ \\
\hline & & Massive angular olivine-rich basaltic blocks on the eastern rim of Bory crater & 240 \\
\hline \multirow[t]{5}{*}{ Maillard (1862) } & \multirow[t]{2}{*}{1851} & Bory still inactive & 128 \\
\hline & & Active lava lake in a new pit crater named Cratère Brûlant, $\sim 1 \mathrm{~km}$ east of Bory & 129 \\
\hline & \multirow[t]{3}{*}{ January-March 1860} & $\begin{array}{l}\text { Overflow from the lava lake (January 22-February 5) followed by its progressive draining } \\
\text { related to flank eruptive fissures feeding voluminous lava flows (February 7-March 17). }\end{array}$ & $107-108$ \\
\hline & & Summit explosions associated with a massive dark plume and bomb ejections (March 19) & 108 \\
\hline & & $\begin{array}{l}\text { Block and ash deposit covering the Central Cone. Enlargement of Cratère Brûlant from } \\
100 \mathrm{~m} \text { to } 400 \mathrm{~m} \text { across }\end{array}$ & 110 \\
\hline \multirow[t]{3}{*}{ Velain (1878) } & \multirow[t]{3}{*}{ September 1874} & Two new craters in Bory and the related spatter deposit on its western rim & 108 \\
\hline & & $\begin{array}{l}\text { U-shaped collapse structure between Bory and Cratère Brûlant with intense fumaroles } \\
\text { emitted from the ring fractures on its border }\end{array}$ & $109-110$ \\
\hline & & Cratère Brûlant inactive. Velain names it Dolomieu & 115-116 \\
\hline \multirow[t]{2}{*}{ Lacroix (1936) } & \multirow[t]{2}{*}{1911} & The summit U-shaped structure first observed by Velain is named Enclos Velain & 57 \\
\hline & & $\begin{array}{l}\text { Lavas fill the Cratère Brûlant to form a small plateau. Beginning of the formation of a } \\
\text { new collapse structure in the NE part of the plateau }\end{array}$ & 56 \\
\hline Aubert de la Rüe in Lacroix (1936) & October 28, 1930 & $\begin{array}{l}\text { Enlargement of the new collapse structure in a 400-500-m-wide and 50-m-deep } \\
\text { crater (Gratère Brûlant). }\end{array}$ & 56 \\
\hline
\end{tabular}


a spherical shape approximation. Field inspection was carried out to validate the block map in several sectors and the estimated average diameter. Field work confirms our analysis of the photographs but indicates that it is not representative of the distribution of clasts smaller than $5 \mathrm{~cm}$ in MD that are abundant in most sectors.

Finally, we described the stratigraphy of the Central Cone from highresolution mosaic images $(\sim 10 \mathrm{~cm}$-wide pixels; Fig. $2 \mathrm{~b})$ to infer the prehistoric volcanic activity (i.e., before the first description of the summit in $1751 \mathrm{CE}$ ) and to evaluate the occurrence of deposits of large explosive eruptions in the past. The resolution of our mosaic is about 10 times higher than that recently used by Peltier et al. (2012) to identify the main units cropping out in the caldera walls.

\section{Results}

\subsection{Historical summit activity}

Our review of the historical eruptive activity of Piton de la Fournaise since the first settlement on La Réunion island in 1640 CE reveals the time distribution of explosive events and their link with summit collapses and effusive eruptions (Fig. 3). Analysis of temporal evolution in the activity of Piton de la Fournaise permits the identification of two main, and previously unreported, clusters of explosive events. The oldest period produced sustained, frequent, long-lasting effusive activity (1708-1878) and was characterised by frequent and violent explosions. The second and youngest cluster (1897-2012) produced short-lived, discrete effusive eruptions and only rare and, on average, weaker explosions than those in the first cluster (Fig. 3). Summit collapses occurred during both clusters and correspond to periods of frequent eruptive activity. These summit events were systematically associated with lateral eruptions and were followed by a significant decrease in eruptive rate (Fig. 3 ).

Historical reports permit detailed reconstruction of the morphological evolution and the eruptive activity of the summit cone during the last three centuries. Only fragmentary and qualitative accounts exist about volcanic activity during the first 70 years of human settlement on La Réunion island (Fig. 3). The first description of an ascent to the summit of Piton de la Fournaise was made by Dolnet de Palmaroux in 1751 (d'Heguerty, 1755). At that time, the volcano was described as inactive but releasing intense heat from the summit crater. Interestingly, the lava field covering the Enclos Fouqué caldera was reported to be shining so brightly to blind the explorers (d'Heguerty, 1755; pp. 226; Table 1). Such effects (heat and shining) suggest that the explorers observed a field of freshly emplaced pashoehoe lava flows in the Enclos Fouqué caldera, possibly fed by the long-lasting activity of the summit Bory crater (Lénat et al., 2001). This hypothesis is also consistent with the report in 1733 of volcanic activity so intense that it shed light during nighttime as far as La Réunion's north coast (in Sainte Suzanne, 40 km

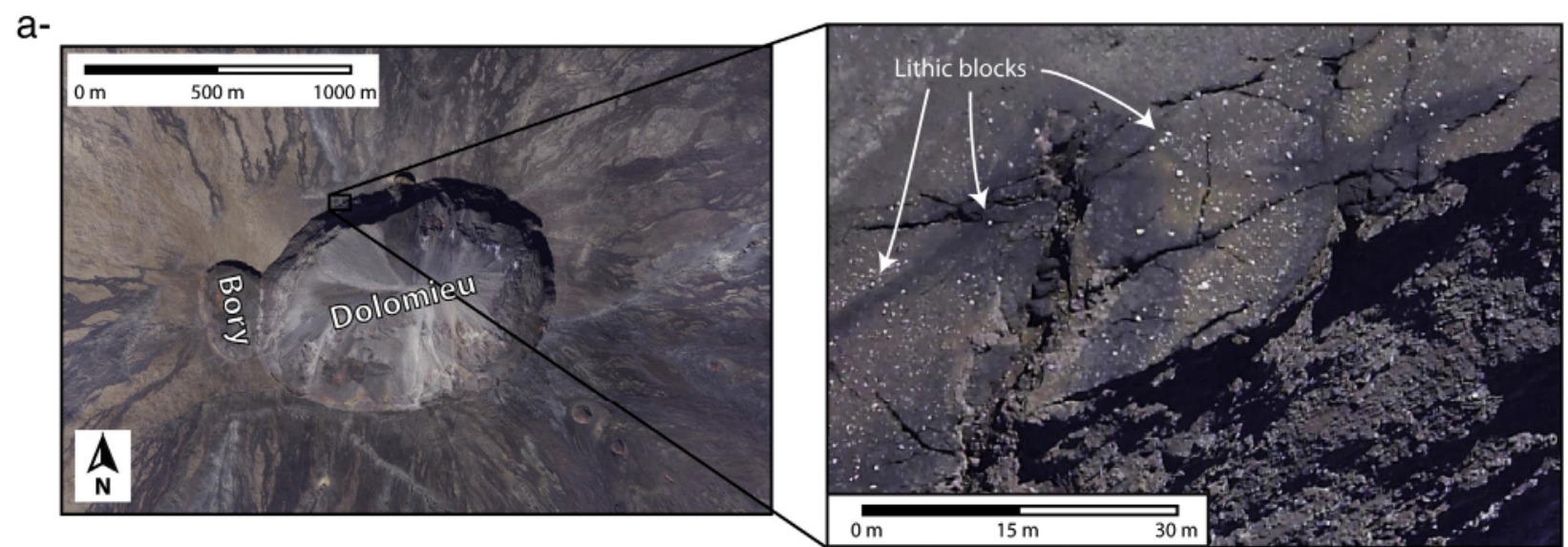

b-

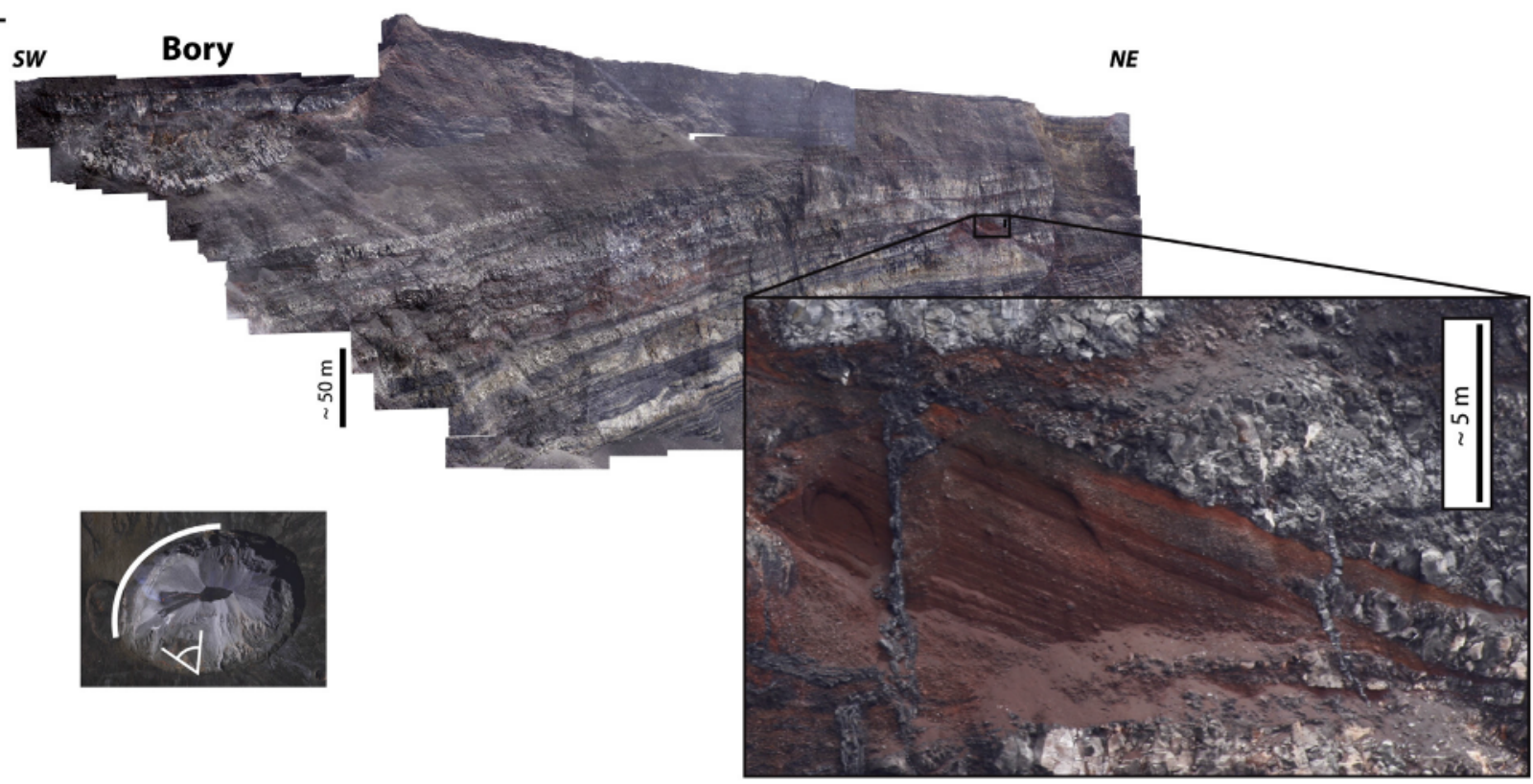

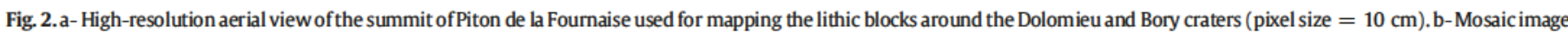
of the northwestern wall of the Dolomieu caldera. Each mosaic has been prepared from a series of high resolution photographs with an average pixel size of $10 \mathrm{~cm}$ 


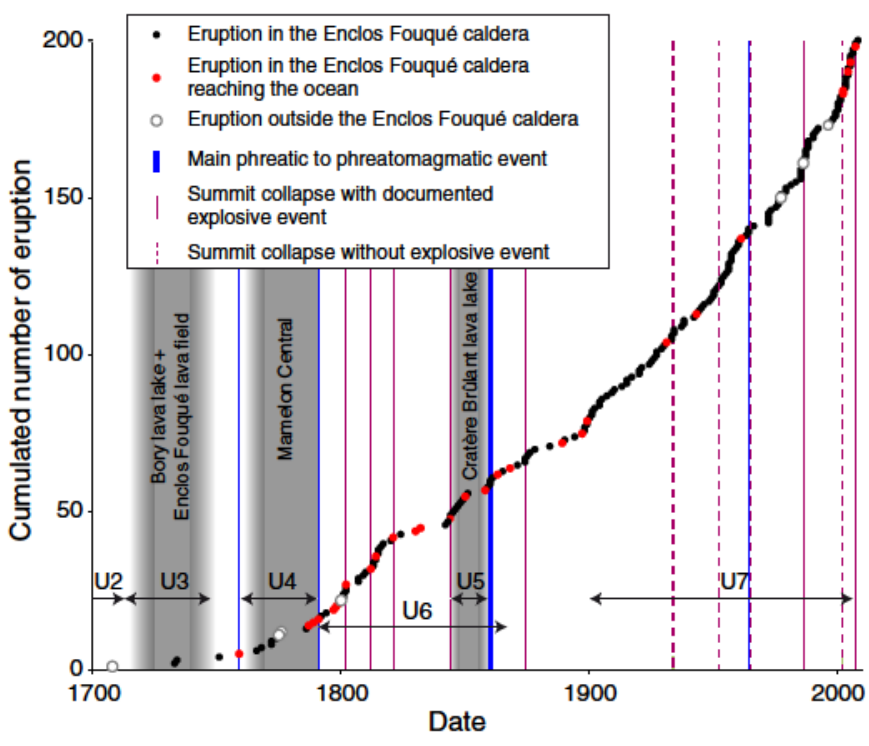

Fig. 3. Temporal distribution of eruptive activity (dots), summit explosions and summit collapses (vertical bars) of Piton de la Fournaise between 1708 and 2012. Dots are red when the lava flow inside the Enclos Fouqué caldera was voluminous enough to reach the ocean, and white when the feeder dyke propagated along the rift zones outside Endos Fouqué caldera (Fig 1). Grey areas depict approximate duration of continuous summit activity. $U 2$ to $U 7$ refer to litho-stratigraphic units identified in the summit caldera walls and described in Section 3.3.

from the volcano's summit; Maillard, 1862, pp. 130). These observations strongly suggest that at least part of the large lava field emitted by Bory crater and now covering the floor of Enclos Fouqué caldera (Champ de Lave de l'Enclos Fouqué, CLEF: Enclos Fouqué lava field; Fig. 1) was emplaced in the decades immediately preceding Dolnet's expedition in 1751, and not after 1750 as suggested by Lénat et al. (2001) and
Peltier et al. (2012). We note that our interpretation of historical accounts is in agreement with recent archeomagnetic data of CLEF lavas (Tanguy et al., 2011).

The second (1768) and third (1772) known expeditions to the volcano summit were conducted after the large 1759 explosive event. It corresponds to the first explosive eruption described in historical accounts at Piton de la Fournaise (de Crémont, 1770; pp. 94; Fig. 3). During this eruption, a new summit crater formed (ID \#4 in Fig. 4), and fine-grained ash was deposited up to $50 \mathrm{~km}$ far from the summit (de Crémont, 1770; pp. 94). Both expeditions reported the occurrence of lava fountains at the summit (inside today's Dolomieu crater) emitted by a steep pyroclastic cone (later named Mamelon Central, located about 300 paces away from an inactive crater) and shedding discrete dark ash pulses (de Crémont, 1770; pp. 87-89; de Montessus, 1889; pp. 154; Table 1). Interestingly, the explorers described a highly vesiculated spatter deposit related to this activity that was covering most of the surface of the summit (de Crémont, 1770; pp. 90). We describe this deposit in the following paragraphs.

The first detailed and precise description of the summit was made in October 1791 during an expedition after the large explosive event of July 1791 (Bert in Lacroix, 1936; pp. 39-41). The volcano's summit was then characterised by (1) an inactive crater in the west (ID \#2-3 in Fig. 4), probably the one previously described successively by Crémont and by Commerson (de Crémont, 1770; Commerson in de Montessus, 1889), (2) a 50-m-high inactive spatter cone (Mamelon Central), $350 \mathrm{~m}$ east of the inactive crater, and (3) a 200-m-deep, 180 -m-wide pit crater cutting horizontal lava flows south of the spatter cone (ID \#5 in Fig. 4). According to Bert, the latter formed in 1791 while the large spatter cone was ending its activity (Figs. 3 and 4; Bert in Lacroix, 1936). During the following expedition in 1801 by Bory de Saint Vincent, the western crater, the spatter cone and the 1791 pit crater were baptised Bory, Mamelon Central and Dolomieu, respectively (Bory de Saint Vincent, 1804). The few angular blocks observed by Bory de Saint Vincent on the eastern margin of Bory crater can tentatively be

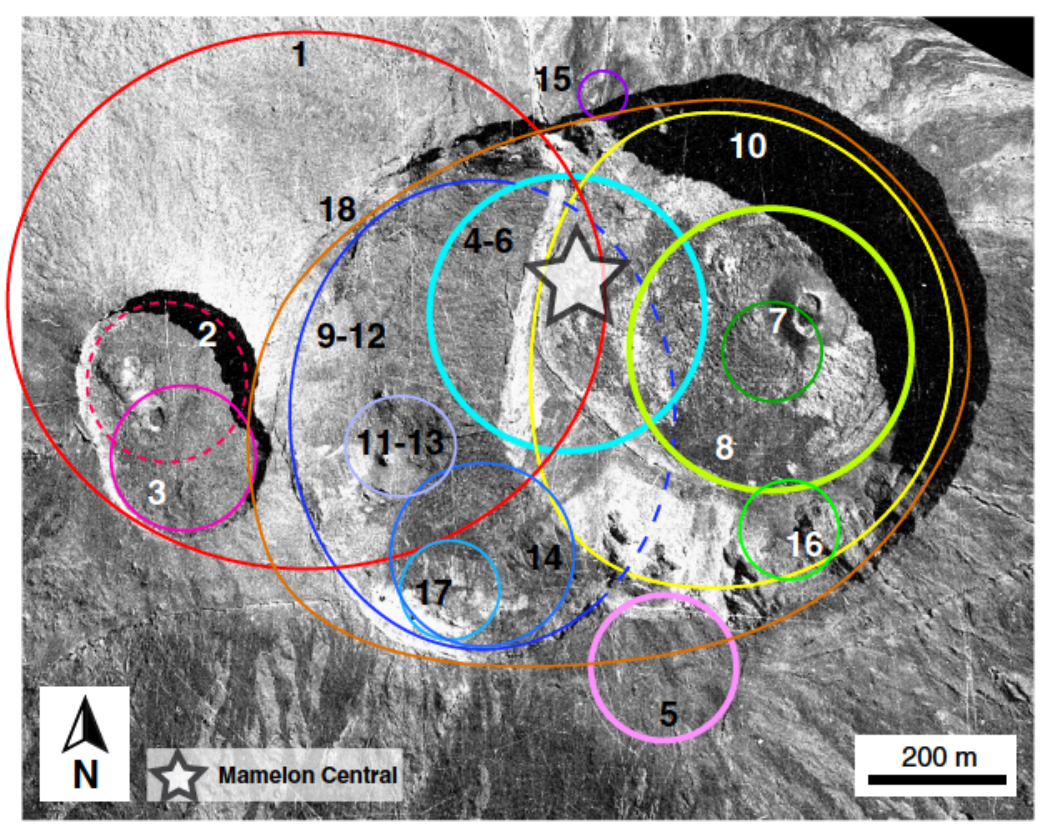

\begin{tabular}{|c|c|c|}
\hline ID number & Date & Name \\
\hline $1-$ & $<1708$ & ${ }_{\alpha}$ Cratère Ouest $x_{a} ;$ Pre-Bory pit crater ${ }_{b}$ \\
\hline $2---$ & $1708 / 51$ & \multirow{2}{*}{ Bory crater ${ }_{c}$} \\
\hline $3-$ & ? & \\
\hline $4=$ & 1759 & «cratère de $1766 m_{d}$ \\
\hline 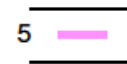 & 1791 & $\begin{array}{l}\text { abouche nouvelle»d } 1 \text { 1791-1801; Dolomieu } \\
\text { crater }_{\mathrm{c} ; 1801-1878 ;} \text { Petit Plateau pit crater } \\
\text { b }\end{array}$ \\
\hline $6-$ & 1812 & $\cdots$ \\
\hline $7 \longrightarrow$ & $1821 / 44$ & «cratère Brûlant"s $\mathrm{e}: 1851$ - 1860 \\
\hline $8=$ & 1860 & $\begin{array}{c}\text { «cratère Brûlant»e }: \text { : } 1860-1878 ; \text { Dolomieu } \\
\text { crater }_{f: 1878-1931}\end{array}$ \\
\hline 9 & 1874 & $\begin{array}{c}\text { Enclos Velain } \\
\text { crater }_{\mathrm{h}: 1911-1980} ; \text { Dolomieu } \\
\end{array}$ \\
\hline 10 & $1931 / 35$ & $\begin{array}{c}\text { "cratère Brûlant»h: 1931-1980； } \\
\text { Dolomieu crater } 1 \text { h:1980-2007 }\end{array}$ \\
\hline $11-$ & 1933 & $\ldots$ \\
\hline $12-$ & $1934 / 35$ & $\cdots$ \\
\hline 13 & 1953 & $\ldots$ \\
\hline 14 & 1961 & $\cdots$ \\
\hline 15 & 1964 & Soufrière pit crater \\
\hline $16-$ & 1986 & $\cdots$ \\
\hline 17 & 2002 & $\cdots$ \\
\hline 18 & 2007 & Dolomieu caldera $_{\mathrm{g}}$ \\
\hline
\end{tabular}

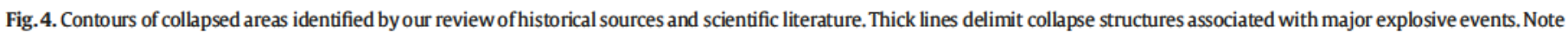
the Bory 1 crater (associated with lithostratigraphic unit $U B$ described in Section 3.3.) cut by the subsequent collapse of Bory 2 pit crater. 
attributed to explosive events during the final eruptive activity of several centres like the Bory crater, the Mamelon Central and the 1791 crater.

Between 1801 and 1851, at least four eruptions (1802, 1812, 1821 and 1844) were associated with small ash plumes at the summit and the lateral effusion of voluminous lava flows (Bory de Saint Vincent, 1804; Maillard, 1862; Fig. 3). The concomitant destruction of the Mamelon Central indicates that the summit area experienced collapses at that time (Fig. 4).

The description of Maillard (1862; pp. 128-129; Table 1), based on his observations of the summit in 1851, reveals an important evolution of the summit structure. The volcano was then characterised by two distinct peaks in the west and east, the western corresponding to the Bory crater (unchanged since 1801). In the east, the new summit was centred on a 100 to 150 -m-wide, 250 -m-deep pit crater named Cratère Brûlant (ID \#7 in Fig. 4), probably formed during the 1821 or 1844 main eruptions. At that time, Maillard observed in Cratère Brûlant, and sketched (Plate IX in Maillard, 1853), the only unambiguous lava lake ever described in historical times at Piton de la Fournaise. In 1858, several explosive events occurred inside the Cratère Brûlant, while abundant lava flows were emitted from the eastern base of the Central Cone (Maillard, 1862; pp. 102-103). Effusive activity resumed in January 1860.

This activity produced the most violent explosive eruption reported in historical records and is here described in detail. At least two explosive events (on February 21 and on March 19) alternated with effusive activity and ash fall blanketed the whole eastern flank of Piton de la Fournaise. The precise description of Maillard (1862; pp. 107-110) (Table 1) indicates that lava was overflowing Cratère Brûlant between January 22 and February 5 . This process ceased when new eruptive fissures successively opened at the eastern base of the Central Cone on February 7 and 17 and on March 11. Each fissure fed large lava flows that rapidly reached the ocean. In the meantime, the level of the lava lake and the magmatic activity in Cratère Brûlant progressively decreased until the beginning of March. On March 19, the main explosive phase began with a violent explosion followed by a continuous emission of ash and blocks that fed a large plume lasting several hours (Hugoulin, 1860). Maillard's observation made soon after the eruption indicates a widespread ash deposit in the Enclos Fouqué caldera and a layer of blocks (from several cubic metres to much smaller in volume) scattered over the summit and inside Bory crater ("L'ensemble du cône s'est exhaussé d'une immense couche de blocs de toute grosseur, depuis plusieurs mètres cubes jusqu'aux fragments les plus petits." Maillard, 1862; pp. 110). Maillard (1862) also mentions that few blocks were already present before 1860 ("Déjà antérieurement, nous avions vu de pareilles roches aux environs du cratère, mais en très petite quantité"). The geometry of Cratère Brûlant evolved from a 100 to 150 -m-wide pit crater before the eruption to a 400 -m-wide funnel-shaped crater afterward (ID \#8 in Fig. 4; Maillard, 1862). This final geometry did not change until the ascent of Velain in 1874 . The main modification described by Velain (1878; pp. 109-110) is the development of a U-shaped collapse structure between Bory and Cratère Brûlant, later named Cratère Velain (Lacroix, 1936; pp. 57; ID \#9 in Fig. 4). The intense fumarolic activity along the ring fractures and the summit explosions observed during the July 1874 main eruption, 2 months before Velain's expedition, suggest that the collapse occurred during this main eruptive event (Fig. 3). The second change described by Velain (1878) is the formation of two small pyroclastic cones inside Bory crater associated with a spatter deposit thrown over its western rim. Although quite small in volume, the spatter deposit is of paramount importance as it covered and preserved the underlying 1860 phreatomagmatic tephra sequence (see following section).

Only rare and, on average, weak explosive events are mentioned in the post- 1878 reports.

In 1911, Cratère Brûlant was entirely filled and the floor of Enclos Velain and the lava flows emitted from the previous Cratère Brûlant formed a kilometre-long plateau (Lacroix, 1925), as in 2006. New collapse structures developed, first in the eastern part at the location of the preexisting Cratère Brûlant, and then in the western part during and shortly after the large 1931 lateral eruption (Aubert de la Rüe in Lacroix, 1936; pp. 56); (ID \#10-13 in Fig. 4, Table 1). The progressive combination of the eastern and western collapses contributed to form a unique, large, east-west elongate collapse structure named Dolomieu (Bachèlery, 1981). We stress that this new Dolomieu crater does not correspond to the one initially named Dolomieu by Bory de Saint Vincent (1804), formed in 1791 (now Petit Plateau; Fig. 4). Between 1934 and 2006, the summit eruptions inside Dolomieu progressively filled the crater, and in October 2006, lava flowed over the crater's eastern rim. During this period, only small summit pit craters developed and were systematically associated with lateral eruptions (1953, 1961, 1964, 1986, 2002; Ducrot, 1958; Lénat and Bachèlery, 1990; Longpré et al., 2007; Figs. 3 and 4). However, no clear link exists between the lava volume emitted by lateral activity and the occurrence of summit collapses (Roult et al., 2012). Dolomieu crater experienced its largest historical collapse during the April 2007 eruption but neither it nor the main collapse in 1931 or the smaller summit collapses in 1964 and 2002 were associated with sustained ash plumes or major block emissions. The main recent ash plume and block ejection occurred during the 1961 eruption and is described in more detail below. A few blocks were ejected toward the south by the collapse of the 1986 pit crater ( $\mathrm{P}$. Bachèlery, personal communication).

Our historical review reveals that the main explosive events (1759, 1791,1860 ) corresponded to the ending of long-lasting effusive activity at the summit (Enclos Fouqué lava field; Mamelon Central; Cratère Brûlant lava lake). Collapses during the recent period (1897-2012) of discrete eruptions apparently had a lower explosive potential, with the exception of that of 1961. Interestingly, the change from the initial period (1708-1878) with very frequent to sustained effusive activity to the still on-going period of discrete activity (1897-2012; 1 eruption every 9 months on average) occurred during a long interval (18 years: 1878-1897) of low effusive rate (1 eruption every 43 months on average) and long quiescence periods (up to 5 years).

\subsection{Dynamics and deposits of the summit explosive events}

In the following paragraphs, we integrate a set of key observations on the summit eruptive phenomena and their deposits in order to make some inferences on the eruptive dynamics and its evolution during time. We first review the most recent explosive eruptions and then the prehistorical activity, as recorded in the layers recently exposed by the collapse of the Dolomieu caldera.

\subsubsection{Recent collapses and explosive activity (post-1900)}

Only incomplete data exist about the dynamics of recent summit explosive events of Piton de la Fournaise. Since the beginning of the 20th century, ash plumes were only documented in 1961 and 2007 (Fig. 5). Weak ash emission was also reported at the end of the June 2003 eruption (Piton de la Fournaise Volcano Observatory [OVPF] internal reports), which occurred inside the Dolomieu crater, and during the March 1986 eruption (Delorme et al., 1989). In 1986, ash emissions occurred at the distal lateral vent of Takamaka (March 19), while a phreatic explosion accompanied the summit pit crater collapse on March 29. This last event was not directly observed by OVPF because it occurred at 1843 GMT, but the new occurrence of lithic blocks scattered across a small sector close to the collapse area was reported in the following days (P. Bachèlery, personal communication).

The 1961 eruption produced the only major explosive event of recent times, but occurred before the establishment of continuous monitoring by OVPF. In 1961, a lateral effusive eruption started on April 1 along the northern segment of the N25-30 rift zone. The emission rate rapidly increased from April 19 to April 21 when a sustained ash plume ascended during 4-5 h (J. Legros, unpublished data) from a set of vents located on the inner cliff south of the Enclos Velain (Fig. 5a). 

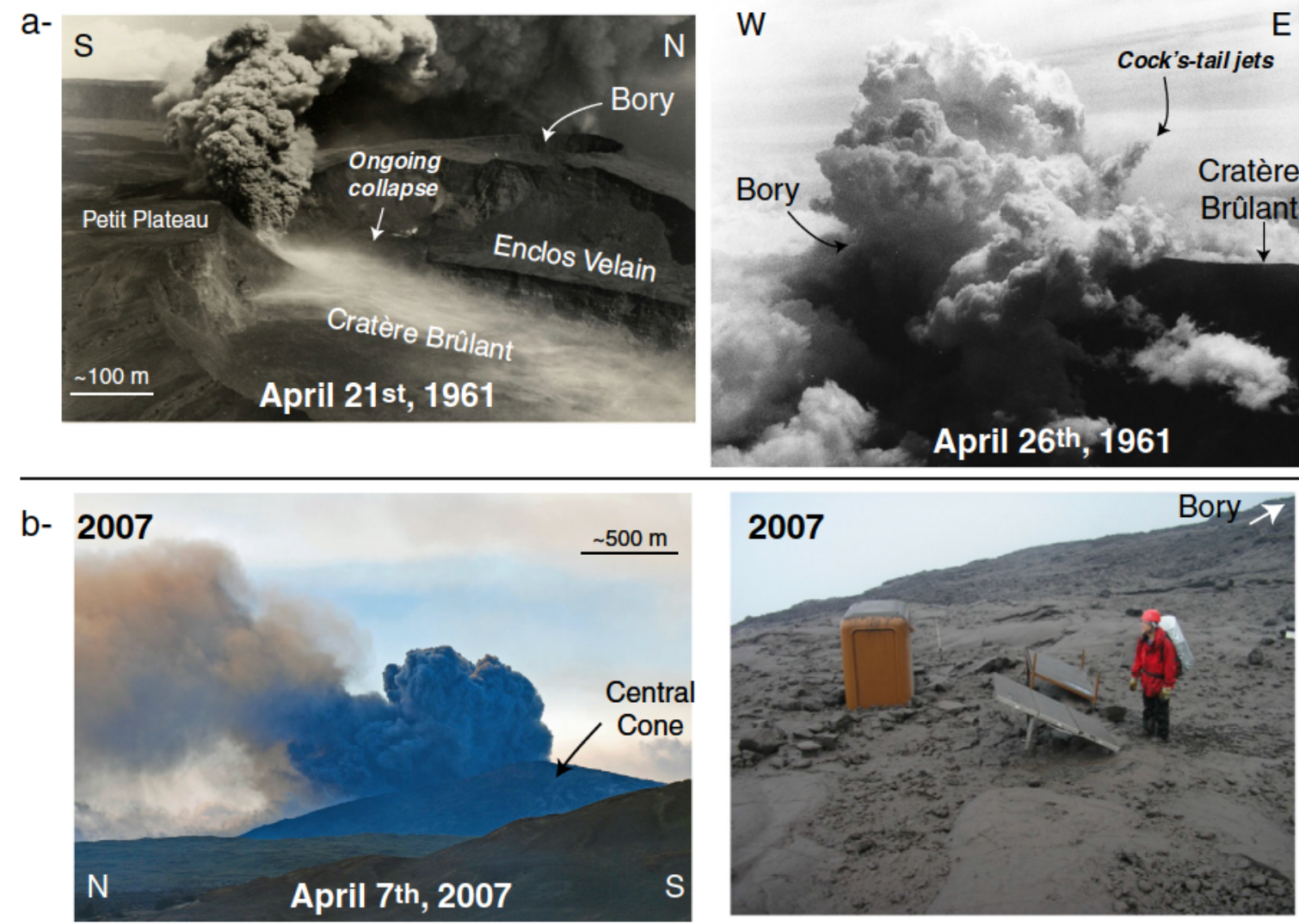

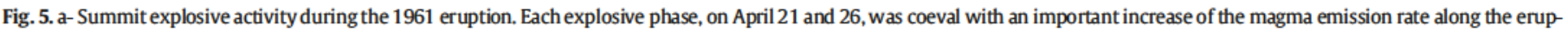

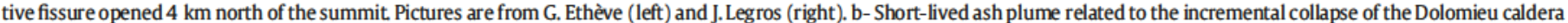
during the April 2007 eruption (left). Fine-grained muddy ash deposit southwest of the summit accumulated between April 5 and April 8 (right).

Our analysis of aerial photographs suggests that this explosive event was coeval with the beginning of the collapse of the southern part of Enclos Velain, which was marked by an alignment of new fumaroles. The emission rate then declined at the lateral vent until a new summit explosive phase on April 26. During this second phase, the lateral eruptive fissures emitted unusually high lava fountains while the summit activity fed a vertical plume associated with lateral explosions characterised by cock's tail jets (Fig. 5a). The lateral effusive eruption rapidly ended after this paroxysmal phase. We have not identified a tephra deposit related to this event.

The major April 2007 eruption resulted in a quite distinct and much weaker explosive sequence despite an eruptive volume and a collapse much larger than in 1961. The caldera collapse occurred during the night of April 5, 4 days after the beginning of a lateral eruption on the eastern flank at low altitude, and it was coeval with an increase of the lava effusion rate (Michon et al., 2007; Staudacher et al., 2009). Smallvolume, minutes-long, $0.2-0.9-\mathrm{km}$-high ash plumes were emitted during the progressive caldera enlargement, which lasted from April 5 to April 12 (Fig. 5b). Fine-grained muddy ash accumulated during this period, mostly on the southwestern part of the summit (Fig. 5b). Only isolated lava blocks were scattered on the eastern rim of Dolomieu above the 2006 lava field. The ash deposit sampled by members of OVPF near Bory crater comprises three fine-grained $(<250 \mu \mathrm{m})$ ash layers. At the base, Layer 1 is a $<1$-cm-thick vitric black ash deposit, overlain by Layer 2 made of $<0.7-\mathrm{cm}$-thick pinkish fine ash with abundant Pele's hair. The uppermost layer (Layer 3) consists of $2-2.5-\mathrm{cm}$-thick grey vesicular mud. Layers 1 and 2 are attributed to the (pre-caldera collapse) February 2007 summit eruption and to the initial and most intense phase (pre-caldera collapse) of the April 2007 eruption, respectively. Layer 3 is the main ash layer, which was restricted to the volcano summit during and after the caldera collapse (Fig. 5b).
In contrast to the 1961 eruption, lateral lava effusion continued for three weeks after summit caldera collapse and explosions.

To sum up, only relatively small summit phreatomagmatic (1961) and phreatic (1986 and 2007) explosions with modest lithic block ejections have affected local portions of the volcano summit during the last century. In the three reported eruptions, summit explosions were produced during summit collapses, which were triggered by lateral effusive events. Most interestingly, the intensity and the duration of the explosive events are not proportional to the volume and depth of the summit collapse. For instance, no explosive phase is known for the second 1931 summit collapse, which ranks second in volume and depth in recent times.

\subsubsection{Historical collapses and explosive eruptions (pre-1900)}

In our review of historical sources, we recognised 8 explosive events in the period 1700-1878. In the field, only three lithic-rich units were identified around the summit craters that we attribute to the main known historical explosive events. Those units are described here from oldest to youngest.

3.2.2.1. Unit A: "Black unit" deposit (possible age: 1759-1791 CE). The "Black unit" crops out on the northern and southern rim of Dolomieu (Fig. 6). The unit grades from micro-vesicular lava at the base, to spatter and loose glassy scoriae at the top. Scoriae have a very distinctive texture, with well-developed glassy breadcrust surface, commonly elongated shapes with orthogonal cracking. The whole unit is up to $4 \mathrm{~m}$ thick on the northern rim of Dolomieu but much thinner on the southern rim $(<0.5 \mathrm{~m})$. Decimetric lithic blocks (dense grey lava) are common, scattered inside the deposit (Fig. 6a).

The stratigraphic position and the wide distribution and the texture of the lava are fully compatible with the products emitted by the long- 
a-

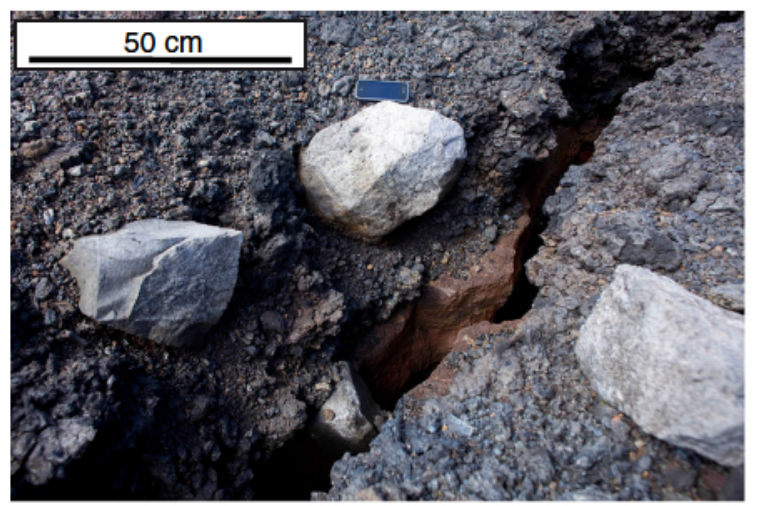

C-

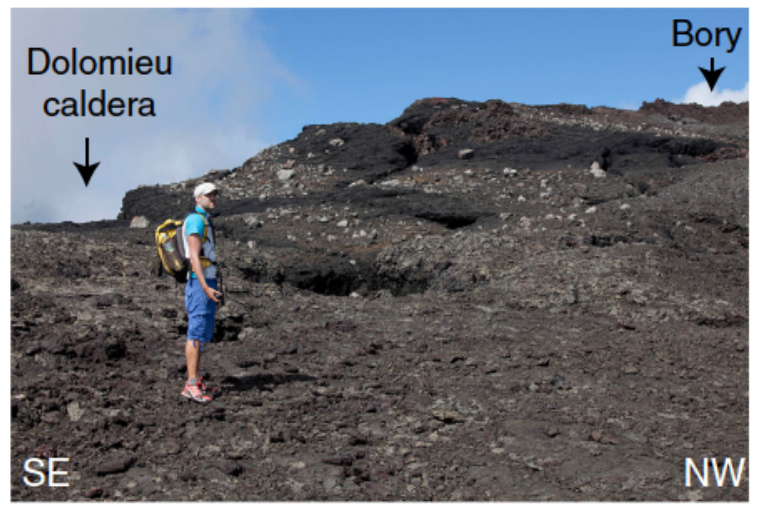

b-

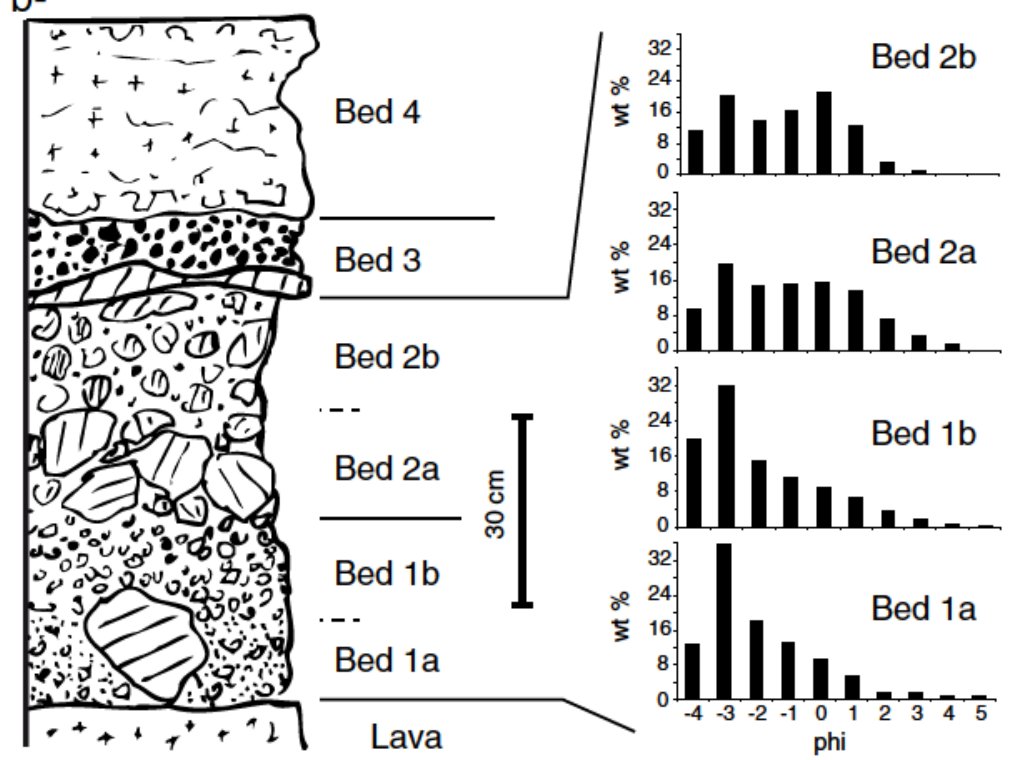

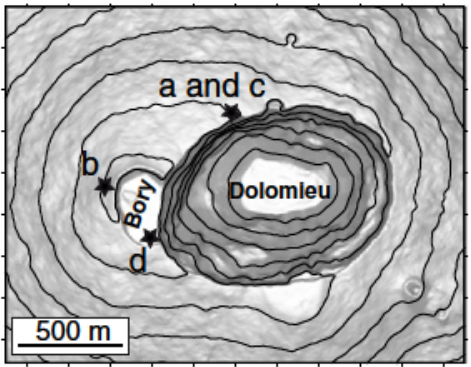

d-

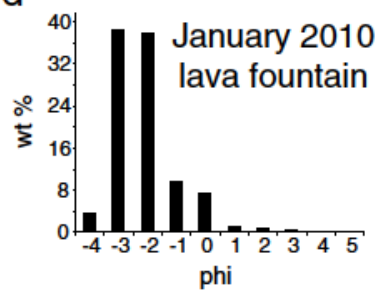

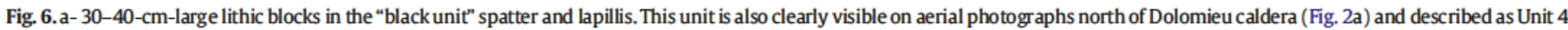

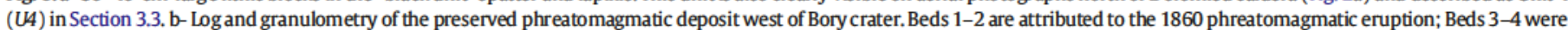

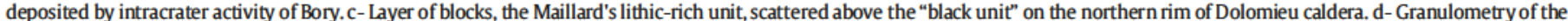

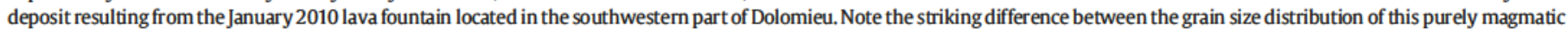
event and those of Beds 2 and 3, which are related to phreatomagmatic to phreatic events.

lasting activity of Mamelon Central as reported by Crémont in 1768 (de Crémont, 1770; pp. 94).

3.2.2.2. Unit B: "Bory west tephra sequence" (possible age: 1860 CE). On the outer western rim of Bory crater, a lithic-rich pyroclastic sequence is covered by and preserved under spatter and clastogenic lava. The spatter and lava unit were erupted during activity of two scoria cones located inside the northwestern portion of Bory crater and first observed in 1874 (Velain, 1878; Fig. 7). Consequently, the deposits below the lava and spatter are likely to correspond to the major 1860 event reported by historical accounts as the most intense of historical time. Deposits of older eruptions would have been rapidly eroded and reworked by the very intense rainstorms that often drench the summit area. The pyroclastic sequence is weakly stratified and can be subdivided into two main beds. The lower portion, Bed 1, is formed by two layers (1a and 1b) of poorly-sorted lapilli, with variable matrix contents, having a maximum total thickness of $30 \mathrm{~cm}$. The overlying Bed 2 contains two layers ( $2 \mathrm{a}$ and $2 \mathrm{~b}$ ) of clast-supported lithic breccia (maximum total thickness: $35 \mathrm{~cm}$ ), with low matrix content. This sequence underlies a thin bed, Bed 3, formed by a discontinuous layer of spatter and a layer of black lapilli. Beds 1 to 3 are covered by a clastogenic lava unit, Bed 4 (Fig. 6c), which locally drapes the largest blocks of the lithic breccia.
In Beds 1 and 2 , the content of fine ash $(<4$ phi) is very low ( $<1$ wt.\%). The matrix of Beds 1 and 2 share moderate sorting ( $\sigma \mathrm{d} \phi$ : 1.8-2 phi). The lapilli of Bed 1 are coarser (median grain size Mdd: $-2.4 \mathrm{phi})$ than the interstitial matrix of $\operatorname{Bed} 2$ (Md $\phi:-1.5$ phi to $-1.8 \mathrm{phi})$.

In both Beds 1 and 2, the portion of the deposit finer than $3 \mathrm{~cm}(<-5$ phi) consists of scoriaceous lapilli with a cauliflower texture and abundant angular lithic fragments. In the 1-cm-size fraction, the lithic proportion increases from 16-24 wt.\% in Bed 1 to $32 \mathrm{wt} \%$ in Bed 2. In both beds, lithic fragments consist of slightly altered, dense grey to reddish basaltic lavas.

The lapilli of Bed 3 are fluidal, glassy and highly vesicular, like those of classical fountains at Piton de la Fournaise. They are clearly distinct from the cauliflower lapilli of Beds 1 and 2, which differ from a typical fountain-lapilli bed (like those of Bed 3 and the January 2010 deposit; Fig. 6d) because of: i) poorer sorting (standard deviation around the median grain size $\sim 2$ phi instead of about 1 phi, on average), ii) higher proportion of matrix finer than $500 \mu \mathrm{m}$, iii) high lithic content and iv) the absence of fluidal textures.

On the basis of all these observations, we attribute Beds 1 and 2 to different phases of a single phreatomagmatic eruption. Grain-size distribution and componentry suggest a progressive decrease in column 


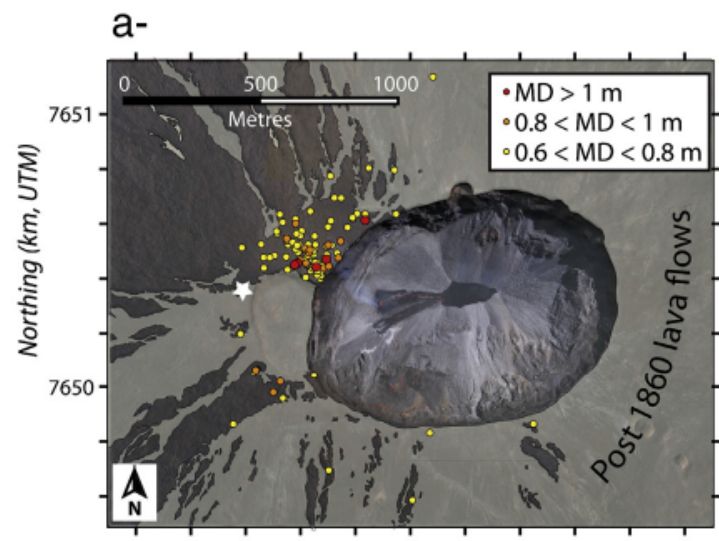

b-
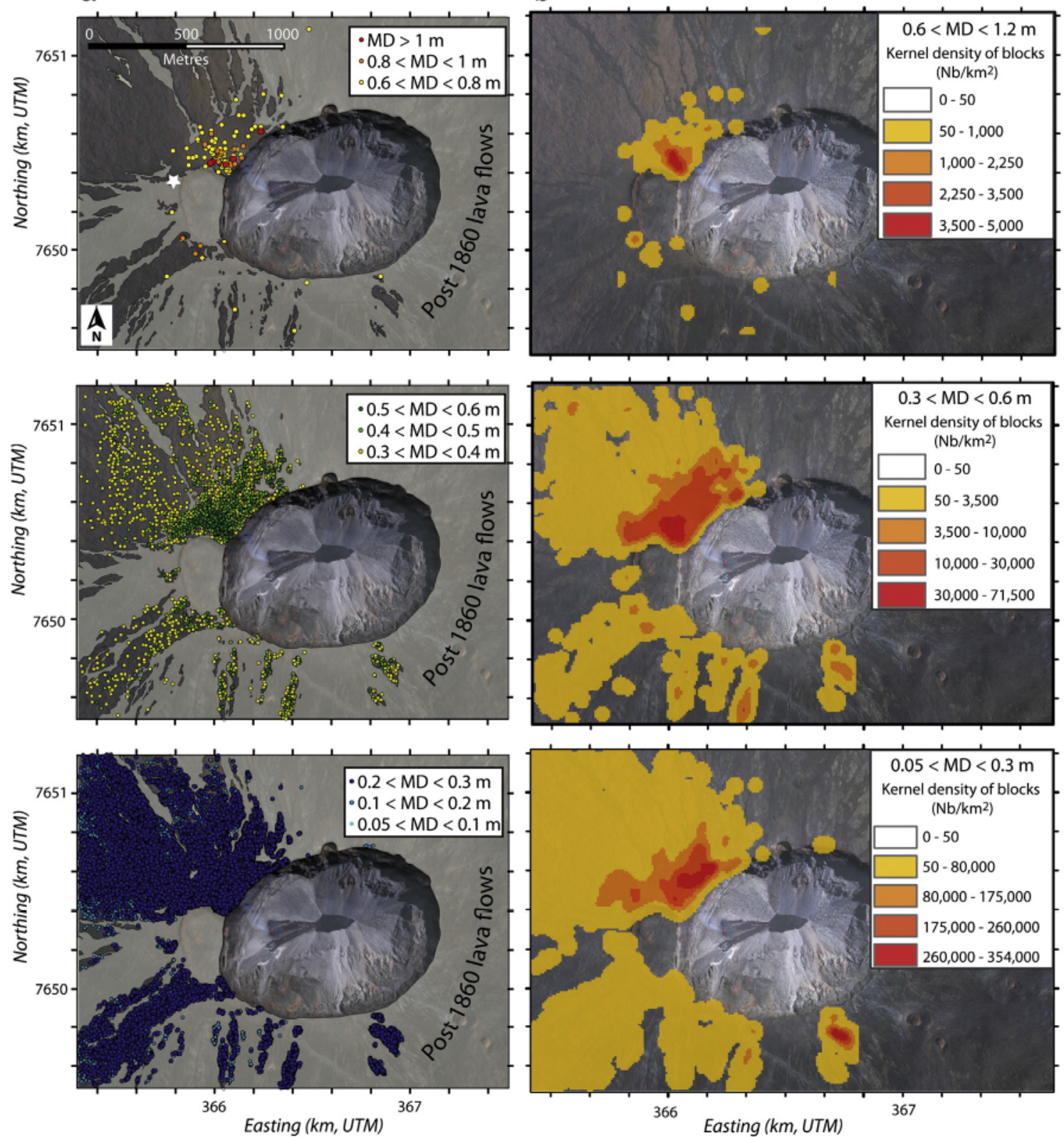

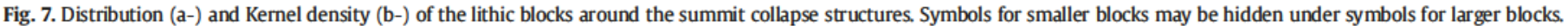
The area covered by post-1860 lava flows is shown in grey. White star indicates the 1860 deposit described in Fig. $6 \mathrm{~b}$.

height concomitant with the late expulsion of large lithic blocks. The deposit sequence we tentatively attribute to 1860 can thus result from an eruptive sequence similar to that observed in 1961, with an initial convective plume followed by lithic block ejections during the final collapse of a summit pit crater.

3.2.2.3. Unit C: "The Maillard's lithic-rich unit" (possible age range: 1791 and younger). A discontinuous bed of lithic blocks overlies the "Black unit" north and southwest of Dolomieu caldera (Fig. 6c). A lithic breccia can also be observed at the surface in several places around the western half of the summit cone, thinning eastward. Very few blocks occur inside Bory crater, and none are observed on the surface of Petit Plateau crater in the south and above the spatter unit on the western rim of Bory. The breccia consists of $\mathrm{cm}$ - to $\mathrm{m}$-sized dense lava blocks ranging from aphyric basalt to olivine-rich oceanite, independent of their location. Some blocks exhibit cooling joints. It is unclear whether the joints are related to cooling of the block itself, inherited from previous cooling or both.

Using our set of high-resolution aerial photographs, 54,441 lithic blocks were mapped around the summit craters. Due to the coverage of our images, the outer limits of the block deposit were not identified. However the limits correspond to zones of steep slopes $\left(>20^{\circ}\right)$ on which small blocks rolled from their initial landing spot. Fig. 7 reveals a strongly asymmetric distribution of blocks around Dolomieu caldera. Most are visible on the northwestern margin of the caldera, a few radial corridors of blocks are mapped on its southern margin and no block can be recognised in the eastern sector. At Kilauea, the asymmetric distribution of the ballistic blocks around the caldera has been directly related to the variability in location or explosive directions of ejection (Swanson et al., 2012a). In the case of Piton de la Fournaise, the block deposit has been partially overlapped by recent lava flows of the 20th and 21st centuries and, locally, by the spatter deposit that preserved the 1860 phreatomagmatic unit west of Bory (Fig. 7). The proximal margins 
of the deposit correspond to the 2007 Dolomieu caldera and the Bory crater, which is filled by lava flows younger than at least 1937 and by two pyroclastic cones formed before 1874 .

The largest blocks, MD between 0.6 and $1.15 \mathrm{~m}$, are concentrated between the northwestern and northern limits of Dolomieu and Bory, respectively (Fig. 7a). Note that the few large blocks (MD $>0.5 \mathrm{~m}$ ) found on the steep slopes of the cone at distances larger than $300 \mathrm{~m}$ from the rim of Dolomieu probably bounced or rolled down the on steep slopes after ballistic emplacement. By contrast, the overall density distribution of blocks of $0.3-0.6 \mathrm{~m} \mathrm{MD}$ is concentric around much of the Dolomieu caldera (Fig. 7b). All block classes with $\mathrm{MD}<0.3 \mathrm{~m}$ share a similar spatial distribution with maximum concentration around the northwestern rim of Dolomieu and east of Petit Plateau (Fig. 7b). This size class includes the most frequent size of the blocks (MD: $25 \mathrm{~cm}$; Fig. 8).

Block distribution suggest different sources of ejection, one inside Bory crater as revealed by the largest blocks close to its nothern rim and the others inside Dolomieu crater. According to our historical review, the main events of block ejection could correspond to the 1791 and 1860 summit collapse events. In particular, the 1791 event could have dispersed the small blocks close to the Petit Plateau near the Dolomieu southern rim. The large 1860 event may have dispersed blocks all around Dolomieu caldera. Those blocks are capped by the spatter layer emplaced on the western rim of Bory just before 1874.

As already pointed out by Bory de Saint Vincent (1804) and Maillard (1862), most blocks have little or no alteration. This suggests either a lack of hydrothermal circulation in the dense layers disrupted by the explosions or explosion affecting shallow levels, possibly above the top of the water table, which lies at $400-500 \mathrm{~m}$ depth below the summit (Join et al., 2005). The second hypothesis seems supported by the absence of intrusive (gabbroic) blocks in the deposit, whereas both hydrothermal products and gabbros are present in older deposits outside the Enclos Fouqué caldera (Bachèlery, 1981).

A shallow origin of the explosions is further supported by the small volume of the Maillard's lithic-rich unit inferred from our aerial photographs $\left(316 \mathrm{~m}^{3}\right)$, though this is clearly only a minimum volume. Assuming a relatively uniform initial distribution of the deposit all around the summit craters that was subsequently overlapped by lava flows, the minimum volume can be extrapolated to c. $1028 \mathrm{~m}^{3}$ for the entire zone. This estimate includes the Dolomieu's surface but does not take into account a possible voluminous ultra-proximal block deposit. Although this value gives only a rough estimation, it represents a very modest volume (corresponding to a lava cube $10 \mathrm{~m}$ on a side), several orders of magnitude smaller than that of the small summit pit crater (e.g., $80 \times 10^{3} \mathrm{~m}^{3}$ and $1.4 \times 10^{6} \mathrm{~m}^{3}$ for the 1953 and 1986 pit craters, respectively). It also suggests that the co-eruptive enlargement of the diameter of Cratère Brûlant from $150 \mathrm{~m}$ to $400 \mathrm{~m}$ cannot be

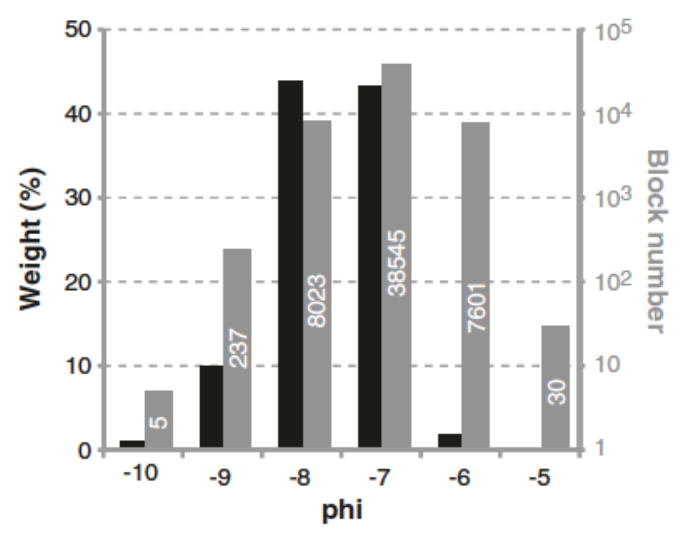

Fig. 8. Size distribution of the blocks in the Maillard's lithic-rich unit. The weight of each block of dense lava is estimated for a spherical geometry of radius MD and a density of $2.7 \mathrm{~kg} / \mathrm{m}^{3}$. Numbers in the bars indicate the number of individual blocks in each class. accounted for by a process of block ejection. This interpretation is consistent with the recent observation that the collapse of the 2007 caldera occurred without significant emission of lithic blocks.

At least part of the block layer on the summit of Piton de la Fournaise could have been emplaced during the 1860 event. If this interpretation is correct, the Maillard's lithic-rich unit could partially correspond to a lag produced by selective erosion of the fine matrix of Unit B where it was not protected by a lava/spatter unit. Our spatial analysis reveals that the block layer must be considered as the integral contribution of all explosive events (phreatic and phreatomagmatic) that occurred at the volcano summit since at least 1791 .

\subsection{Structure of the Central Cone}

Our analysis of historical records and eruptive products establishes a clear link between the periods of sustained summit activity (forming lava lakes), the occurrence of summit collapses and the frequency and intensity of summit explosions at Piton de la Fournaise. We now extend our analysis back to prehistoric time by studying in detail the phases of construction and disruption of the Central Cone.

\subsubsection{Litho-stratigraphy of the cone}

Seven lithostratigraphic units have been identified in the wall of the 2007 Dolomieu caldera using our high-resolution images. They are described here, from the lowermost to the uppermost. The lowermost unit (U1) crops out in both the southern and northern walls of the caldera at a minimum elevation of about $2280 \mathrm{~m}$ asl, more than $100 \mathrm{~m}$ above the base of the cone. The lower half of unit $U 1$ is made of abundant, several-metre-thick red spatter deposits alternating with metrethick lava flows (sub-unit U1a; Figs. 9 and 10). In the northern wall only, $U 1 a$ is overlain by a $\sim 90$-m-thick sequence of metre-thick 'a'ā lava flows (sub-unit $U 1 b$; Figs. 9 and 10). The spatial distribution of $U 1 a$ and $U 1 b$ is thus strongly asymmetric around the walls of Dolomieu. The top of U1a lies at around $2490 \mathrm{~m}$ asl in the south but is more than $100 \mathrm{~m}$ lower in the northern wall ( $2380 \mathrm{~m}$ asl; Fig. 10$)$. Unit $U 1 b$ solely crops out in the northern and northeastern walls to an altitude of about $\sim 2470 \mathrm{~m}$ asl. We propose that $U 1$ corresponds to a basal cone with a gentle slope toward the east and an E-W elongation, similar to that of the current Central Cone. U1 roughly corresponds to unit I described by Peltier et al. (2012). However, our high-resolution observations do not confirm the presence of angular blocks related to phreatomagmatic eruptions in the spatter deposits as proposed by Peltier et al. (2012) on the basis of images with lower resolution. These angular blocks correspond to portions of intrusions excavated by erosion. We interpret the eruptive dynamics for $U 1$ to have been purely magmatic, characterised by intense lava fountains associated with effusion. $U 1$ cone is cut by a large collapse structure centred on the northwestern rim of Dolomieu and previously named "pre-Bory pit crater" (Lénat and Bachèlery, 1990; Peltier et al., 2012; Figs. 1b, 4 and 10).

Unit 2 (U2) records the filling of the pre-Bory pit crater. This unit consists of an alternation of relatively continuous, decametre-thick, horizontal, massive lava units (probably solidified lakes) with thinner (metre-thick) 'a'ā lava flows, whose colour changes upward from black to red (Figs. 9 and 10a). Interestingly, neither talus nor scree is observed close to the edge of this large pit crater despite vertical to sub-vertical walls (Fig. 10a). This observation may suggest that the refilling of the crater was almost continuous preventing and/or assimilating talus fallen from the walls of the crater. These processes are clearly facilitated by the repeated occurrence of molten lava producing the thick massive lava units, possibly lakes. A sporadic 8-m-high scoria cone cut by dikes occurs near the border of the pit crater (Fig. 2b).

Unit $U 3$ crops out all around the caldera wall. It is composed, from base to top, of three sub-units ( $U 3 a, U 3 b$ and $U 3 c$ ), the lowest of which $(U 3 a)$ conformably lies on $U 2$. U3a begins with a few thick lava flows similar to those of $U 2$, then abruptly changes upward in a succession of decimetre- to metre-thick lava flows. The piling up of these lava 


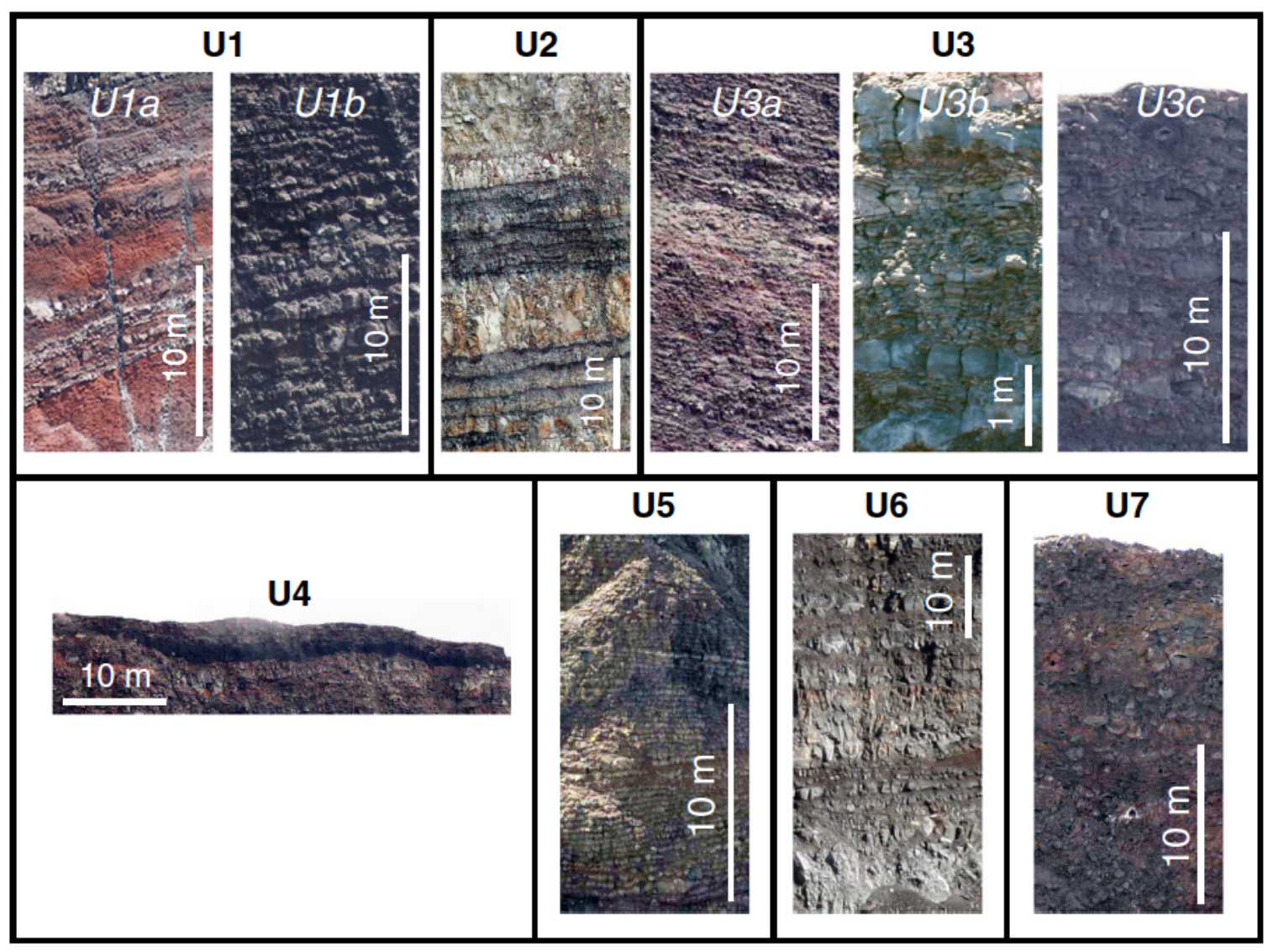

Fig. 9. Litho-stratigraphic units of the summit cone of Piton de la Fournaise determined from the high-resolution mosaic images. See text.

flows built a 150-m-high, relatively flat cone on top of the pre-Bory pit crater (Figs. 9 and 10a). To the southwest, this cone is confined by the wall of the pre-Bory pit crater, whereas it caps $U 1$ and $U 2$ toward the north (Fig. 10a and d). $U 3 b$ and $U 3 c$ sub-units unconformably lie on $U 3 a$. The analysis of the crater walls of Bory clearly shows that subunits $U 3 b$ and $U 3 c$ result from lava flows erupted in Bory crater (Bory 1 in Fig. 4, fill by unit $B_{1}$ in Fig. 10a), and flowing into the northern part of the pre-Bory pit crater. This took place after collapse of part of $U 3 a$ rim and is recorded in the lateral evolution of $U 3 b$, which is characterised by a downstream facies change from an alternation of fragmental deposits and metre-thick lava flows in the northwestern wall of Dolomieu to centimetre-thick lava sheets in the northern proximal-medial area close to Bory crater (Fig. 9). The upper unit (U3c) corresponds to the succession of metre-thick pāhoehoe lava flows, which are in lateral continuity with the widespread Enclos Fouqué lava field described by Lénat et al. (2001).

The lava flows in $U 3 c$ are cut by the collapse of the southern part of the current Bory crater, which is filled by a thick lava unit $\left(B_{2}\right.$ in Fig. 10a). The southern and northern parts of Bory crater are finally capped by lava unit $B_{3}$ (Fig. 10a), which could be associated with the growth of two pyroclastic cones in the western part of Bory crater between 1860 and 1874 .

Unit 4 (U4) corresponds to the "Black unit" described in the previous section (Fig. 5a). It can be traced on both the northern and southern walls of Dolomieu (Figs. 9 and 10) and was already described in the 1980s when Dolomieu caldera was not fully filled (Bachèlery, 1981). In the northern wall, a few lava flows are interbedded within this spatter and scoria deposit. The lithology and spatial distribution of U4 are compatible with spattering and scoria ejection from longlasting lava fountain activity close to the centre of Dolomieu, similar to that described in historical records (de Crémont, 1770; de Montessus, 1889).
According to our interpretation of $U 4$, the younger units (U5, U6, U7) correspond to the activity of the summit cone after 1791. Lavas emitted during these phases were mostly emplaced on the eastern portion of the summit cone, accounting for the apparent asymmetric distribution of the lithic block unit previously described.

Unit 5 (U5) conformably lies on U4 in the northeastern part of the Dolomieu wall, between Soufrière and Petit Plateau (Fig. 10b and c). It is composed of a pile of strikingly homogeneous, $\sim 50$-cm-thick lava flows reaching a maximum thickness of $\sim 20 \mathrm{~m}$ in the northeastern wall. This spatial distribution suggests a vent location in the eastern half of Dolomieu, where Cratère Brûlant formed.

Unit 6 (U6) corresponds to the infill of a collapse structure formed in 1791 below Petit Plateau (Fig. 10d). U6 has similar characteristics to those of $U 2$, i.e. alternation of decametre-thick lava units and metrethick 'a'ã lava flows. The main difference is the existence of scree deposits originating from wall destabilisation following recent summit collapses in $U 6$ but not $U 2$.

Unit 7 (U7) is the uppermost stratigraphic unit cropping out in the Dolomieu wall. The unit, mostly pāhoehoe lava flows, caps U4, U5 and U6 in the eastern half of Dolomieu (Figs. 9 and 10). Its thickness progressively increases eastward to a maximum of $25-30 \mathrm{~m}$ in a local collapse structure at the apex of an uncommonly large intrusion sheet (Fig. 10b). As a whole, the distribution of $U 7$ indicates a vent location similar to that of $U 5$, in the eastern part of Dolomieu.

To sum up, this reconstruction of the summit cone indicates that the eruptive centres migrated through time. They were located in the west (below Bory) for the $U 1, U 2$ and $U 3$ phases and on the east (below Dolomieu) for the $U 4, U 5, U 6$ and $U 7$ phases. Moreover, our analysis shows that the upper three-quarters of the Central Cone corresponds to a relatively simple edifice built above a main older cone (U1) by frequent to sustained activity, whose main vestige is represented by the pre-Bory pit lava lake (U2) and its flanks (U1a and U1b). This older 


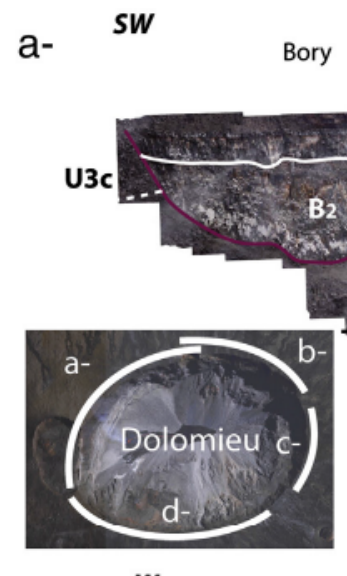

Bory

NE

b-

$w$

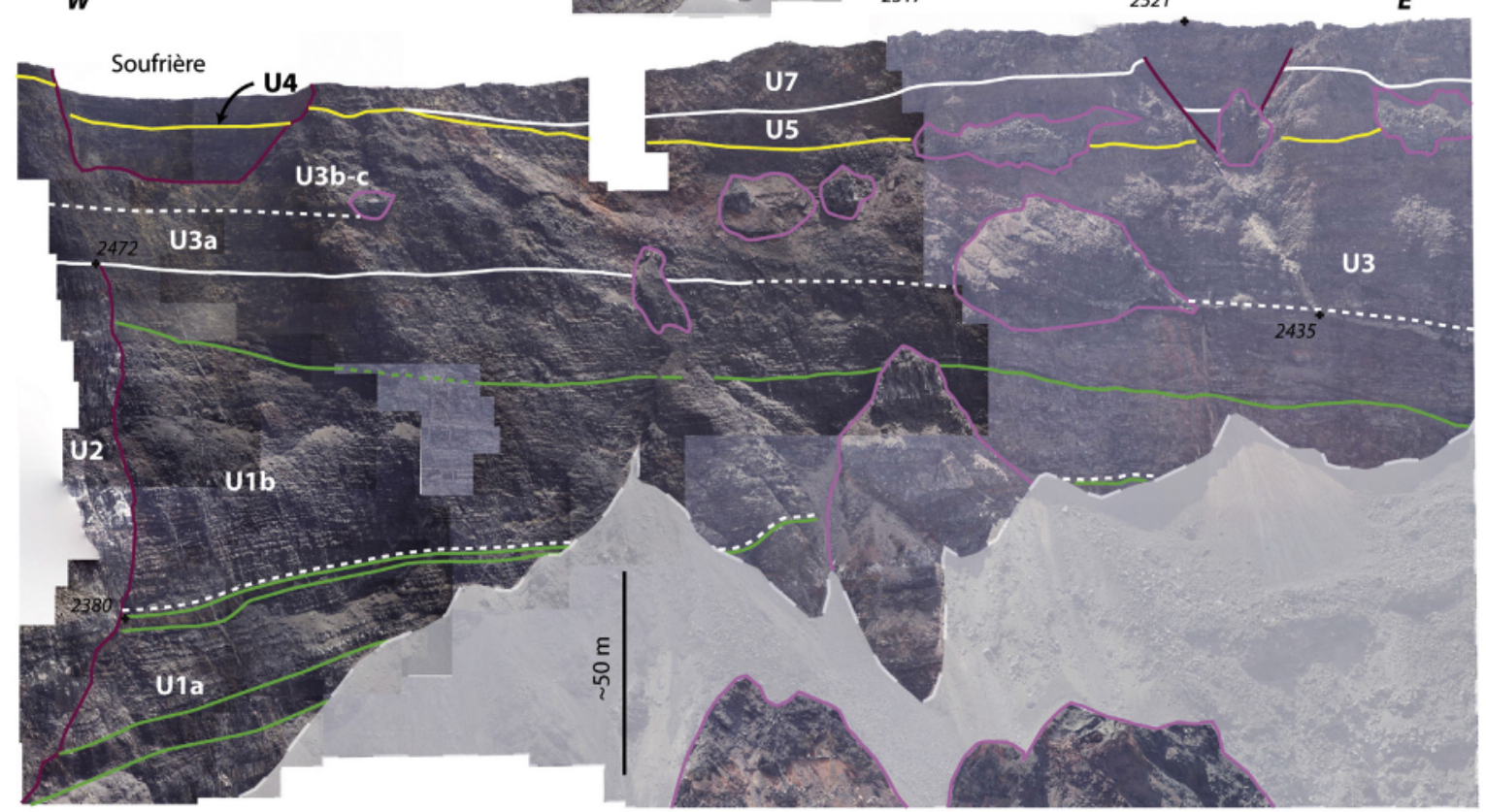

$\boldsymbol{N}$

$S$

C-
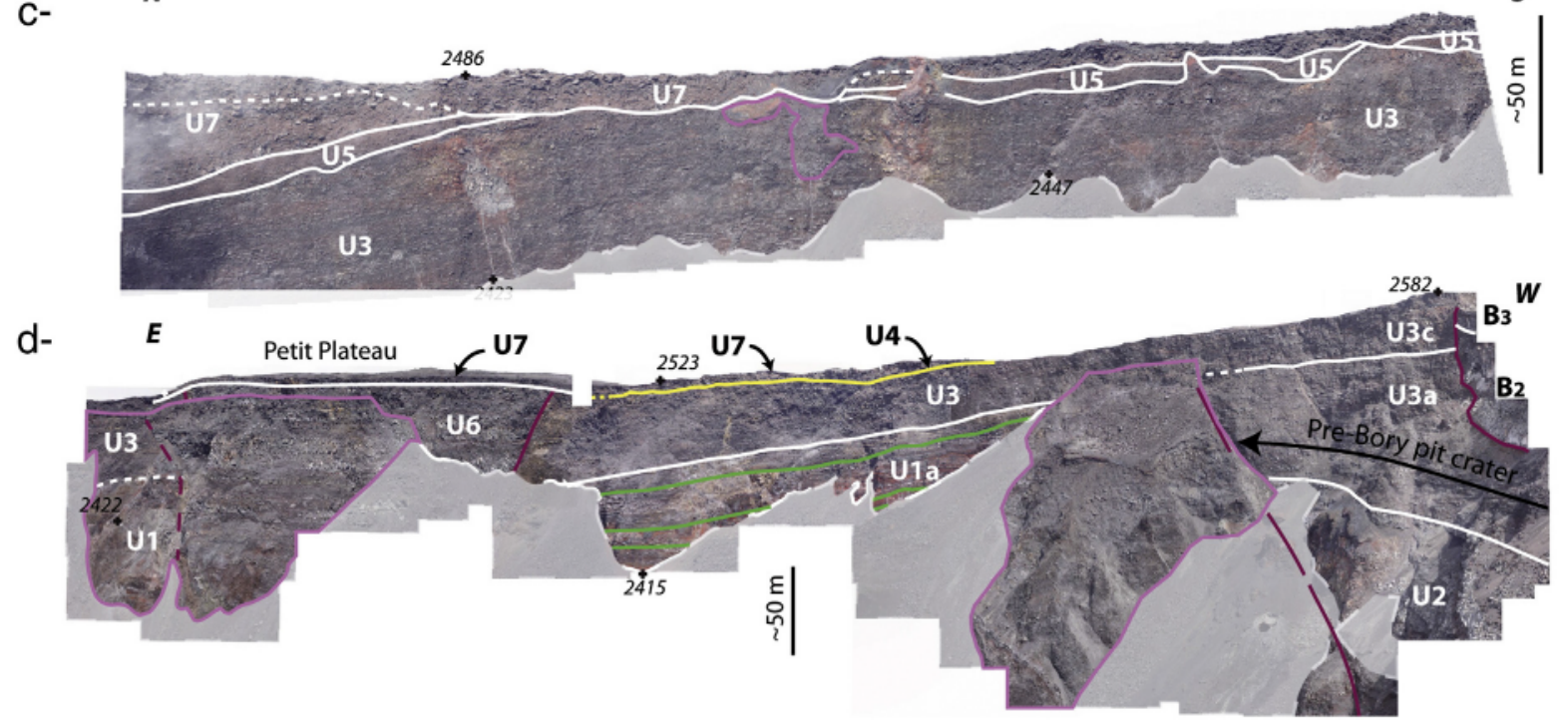

Fig. 10. Distribution of the lava units of the Central Cone of Piton de la Fournaise observed in the western (a), northern (b), eastern (c) and southern (d) walls of the 2007 caldera. U1, U2, U3,U4, U5, U6 and U7 represent the lava units that contributed to the growth of the Central Cone. White, purple, green and yellow lines indicate the contact between the units, the limits of the collapse structures, the main spatter deposits in $U 1$ and a black spatter deposit corresponding to $U 4$, respectively. Scree and talus are represented in grey. Pink lines delimit slide blocks and remaining terraces related to older collapse events. Selected point elevations are shown in metres. 
part of the edifice is capped by the recent (and thinner) products of Bory and Dolomieu craters. Even if lava lakes and long-lasting effusive activity have recently (after 1860) disappeared at Piton de la Fournaise, they represent the dominant behaviour of this eruptive centre in its recent past.

\subsubsection{Preferential intrusion directions}

Our historical and geological analyses confirm that the Central Cone of Piton de la Fournaise has undergone multiple collapse events with a diameter ranging from a few hundred metres to a maximum of $1 \mathrm{~km}$ (April 2007). The analysis of historical eruptions shows that, if summit collapses are systematically triggered by lateral eruptions, the reverse is not true; most lateral eruptions are not associated with summit collapses. The high-resolution analysis of the Dolomieu caldera offers a unique opportunity to compare the spatial distribution of magma intrusions with that of summit collapses.

Our high-resolution images clearly demonstrate that shallow intrusions are almost exclusively vertical: only one metre-thick sill has been observed in the northeastern scarp of Dolomieu whereas 136 vertical dikes have been mapped (Fig. 11). Considering the vertical intrusions only, dikes are mostly sub-radial and, to a lesser extent, sub-parallel to the caldera walls. Radial dikes are concentrated in three relatively narrow sectors, in the northern, southwestern and southeastern caldera walls, independently the height of the caldera walls (Fig. 11). This distribution, in agreement with the rift zone directions (Michon et al., $2009 \mathrm{~b}$ ), indicates magma transfer at shallow depth originating from a common source located below the summit cone. Conversely, the summit caldera forms at the intersection of the three rift zones.

\section{Discussion}

\subsection{Age and dynamics of the Central Cone}

A recent analysis of the walls of the Dolomieu caldera (Peltier et al., 2012) identified three successive stages that contributed to building the Central Cone of Piton de la Fournaise: 1 - sustained, initially explosive activity (lava fountains) changing to effusive activity, which built a large basal cone; 2 - a period of long-lasting effusive activity centred on Bory crater that filled the Pre-Bory pit crater and subsequently

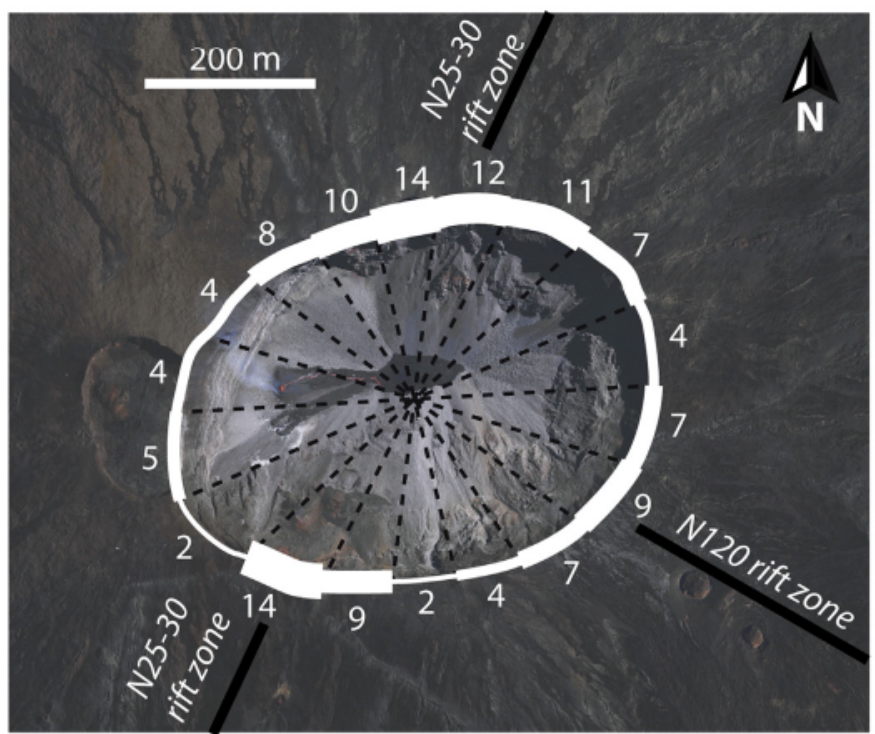

Fig. 11. Dike distribution in the wall of the 2007 caldera. Numbers refer to the dike population detected in each of the 18 sectors. The thickness of the white line is proportional to the dike population. The N25-30 and N120 rift zones previously determined from dike distribution outside the caldera (Michon et al., 2009b) are indicated for comparison built the Bory shield until 1759-1766; 3 - an eastward shift of the active craters centred on Dolomieu crater since 1759-1766.

Our results partly confirm these stages and bring new constraints on the age and the building process of the cone, the evolution in eruptive dynamics, and the implications in terms of volcanic hazard. First, the lowermost unit $U 1$ can result either from a succession of explosive (U1a) and effusive (U1b) dynamics, as suggested by Peltier et al. (2012), or from a single process characterised by sustained lava fountains (U1a) feeding lava flows (U1b) as, for example, observed at Pu'u 'Ō'ō (Kīlauea; Heliker et al., 2003). This second hypothesis fits better with the shape of the basal cone, which is asymmetric, centred below the current Bory crater, and open toward the east. This cone was finally affected by one or more collapses that formed the Pre-Bory pit crater (ID \#1 in Fig. 4), a similar evolution to that of Pu'u 'Ō'ō, which experienced a pit crater collapse in 1987 after the eruption site had moved to Kupaianaha for one year (Heliker et al., 2003). Thus, we propose that a shift from central to lateral activity may have resulted in pit collapse, although the cause of the collapse of the Pre-Bory pit crater cannot be firmly established.

Our analysis indicates that this new pit crater was then filled by thick lava units (U2 phase) related to important, probably almost continuous effusive activity lasting several years to decades (Fig. 10a). An important observation is the interstratification of the final thick lava flows belonging to $U 2$ phase with the first thin lava flows related to the Bory shield (U3 phase). Such a geometrical relationship suggests sustained activity, which first filled the pre-Bory pit crater and then built the Bory shield. The late evolution of the Bory shield was characterised by lava lake activity that fed the CLEF. The final activity of the Bory shield was characterised by overflows from the lava lake (U3b and $U 3 c$ ) and collapse of the southern part of the current Bory crater (ID \#3 in Fig. 4). Historical accounts (d'Heguerty, 1755; Maillard, 1862) and archeomagnetic data (Tanguy et al., 2011) constrain the age of the CLEF to between 1708 and 1751, older than previously proposed (Lénat et al., 2001). In conclusion, we interpret here that $U 2$ and $U 3$ lithostratigraphic units resulted from long-lasting summit activity spanning the 17th century and the first half of the 18th century. If the basal spatter cone only shortly predated the collapse of the Pre-Bory pit crater, in a way similar to the evolution of Pu'u 'Ō'ō described above, then $U 1, U 2$ and $U 3$, which form most of the visible part of the Central Cone, could be related to a single and recent eruptive period centred below Bory crater.

The activity started to shift eastward in $\mathbf{1 7 5 9}$ with the collapse of a new pit crater (ID \#4 in Fig. 4) in which sustained lava fountains spread a black spatter deposit over the summit (U4) and progressively built the Mamelon Central spatter cone. Lava fountains were coeval with discrete explosions as revealed by angular blocks within the deposit. The phase of continuous activity centred on Mamelon Central ceased in 1791 during a lateral eruption that triggered the collapse of Dolomieu pit crater (now Petit Plateau, ID \#5 in Fig. 4)) on the southern rim.

Between 1791 and 1851, the dynamics of Piton de la Fournaise progressively evolved from periods of long-lasting sustained summit activity to a new behaviour characterised by successive discrete summit eruptions, large lateral eruptions (1802, 1812, 1821 and 1844 ) and summit collapses. The latter destroyed Mamelon Central and led to the formation of Cratère Brûlant (ID \#8 in Fig. 4) in which Maillard (1862) observed, in 1851, the lava lake related to the last stage of several-years-long sustained activity of Piton de la Fournaise. The spatial distribution of U5 can be explained by overflows from Cratère Brûlant between 1851 and 1860. The main historical phreatomagmatic eruption of 1860 marks the end of lava lake activity in Cratère Brûlant. Between 1860 and 1911, Cratère Brûlant was filled up by lava flows that formed a new plateau (U7). In the meantime, the dynamics of Piton de la Fournaise evolved toward the on-going phase of alternation of lateral eruptions, which occasionally induce pit crater collapses, and summit eruptions, that progressively fill the collapse structures. 


\subsection{General Implications for the eruptive dynamics of Piton de la Fournaise}

Three key points can be addressed from this reconstruction of the Central Cone development. First, the age of part of the Central Cone exposed after the 2007 caldera collapse is much younger (probably since the 17th century) than that of the Enclos Fouque caldera (4.5 ka; Bachèlery, 1981). This raises the question of the evolution of Piton de la Fournaise in the time between the Enclos Fouqué caldera collapse and the construction of the Central Cone. A phreatic eruption whose deposits are dispersed on the northern rim of the Enclos Fouqué caldera and dated at $2320 \pm 90 \mathrm{BP}$ was interpreted as a product of intracaldera activity (Bachèlery, 1981). These events are much larger than those identified in our analysis, which produced ash deposits too thin to be preserved in the distal areas outside the Enclos Fouque caldera. Moreover, at least two old large scoria and spatter cones (Formica Leo and Puy Mi-Côte) are partially covered by lava flows of the Enclos Fouqué lava field (Fig. 1). These undated cones apparently correspond to eruptive centres, active before construction of the Central Cone.

Second, as already mentioned by several authors (Bachèlery, 1981; Lénat and Bachèlery, 1990; Carter et al., 2007; Peltier et al., 2012), volcanic activity was centred in the western part of the current summit, below Bory crater, during the 17th and 18th centuries, before shifting eastward to the current Dolomieu caldera, in 1759. Peltier et al. (2012) proposed that the migration of the summit volcanic centre resulted from summit collapses that destroyed the underlying magma reservoirs. However, our work shows that the activity remained centred on the summit's western part even after the collapse of the large Pre-Bory pit crater, and started to shift eastward in 1759 even though no collapse had occurred. It is worth noting that geophysical monitoring shows deep seismicity still focused below Bory crater, while shallow hypocenters are typically spread below the whole volcano summit (Battaglia et al., 2005).

Third, during the last centuries, Piton de la Fournaise showed a range in eruptive dynamics larger than previously thought. The first and most intense end-member in this range is characterised by phases of sustained lava effusion that built the basal cone, filled up the Pre-Bory pit crater, and built the Bory lava shield and the Mamelon Central. This period ceased in 1860 after the Cratère Brûlant lava lake activity. One can note that the durations of the two last phases of sustained activity (1759-1790 and 1851-1860) decreased in length. The second end-member, which dominates the still on-going volcano activity after 1878 , is marked by successive short eruptions (lasting several hours to weeks, exceptionally several months) and occasional summit collapses during lateral eruptions. Interestingly, the transition between the two eruptive regimes, which progressively occurred between 1759 and 1878 , was coeval with the eastward shift of the volcanic centre. Assuming that the location of the plumbing system below the Bory crater (Nercessian et al., 1996; Battaglia et al., 2005; Massin et al., 2011) did not significantly change during the last centuries, we propose that both the volcano dynamics and the location of the eruptive centre are controlled by fluctuations in the deep magma supply rate. High magma flux would promote sustained activity at the top of the plumbing system, whereas a lower rate of magma influx would result in discrete activity within Dolomieu coeval with successive pit crater collapses. We speculate here that the long-lasting presence of magma at very shallow depth, followed by a rapid lateral drainage, would produce phreatomagmatic eruptions followed by late pit crater collapse and phreatic explosions. It follows that the current dynamics of Piton de la Fournaise would correspond to a period of relatively low supply rate initiated about 150 years ago. This consideration is of paramount importance for a better evaluation of the volcanic hazard.

\subsection{Cause of pit crater collapse}

In basaltic settings, pit craters develop either at a volcano's summit or in swarms along rift zones (e.g. MacDonald, 1972; Okubo and
Martel, 1998; Rymer et al., 1998; Roche et al., 2001). Collapses of summit pit craters are classically attributed to the draining of shallow magma reservoirs during lateral eruptions (MacDonald, 1972). This mechanism differs from that proposed for pit craters aligned along the rift zones as at Kilauea, where the collapse may result from the interaction between a laterally propagating tensile fracture, filled by magma or not, with structural weaknesses (Okubo and Martel, 1998). In such a model, magma flow would evacuate the stoped blocks and assist the collapse of the cavity's roof.

At Piton de la Fournaise, all the pit craters are restricted to the summit of the Central Cone. The summit Dolomieu caldera is located at the intersection of the two rift zones trending N120 and N25-30 (Fig. 12), where magma first ascends first vertically before its subsequent lateral propagation (Toutain et al., 1992; Peltier et al., 2005; Longpré et al., 2007; Roult et al., 2012). Since 1759 each summit collapse was associated with a lateral eruption. Thus it is likely that the interpretation made for the cause of the 1986, 2002 and 2007 collapses, i.e. the draining of magma stored at shallow depth, above sea level (Hirn et al., 1991; Longpré et al., 2007; Michon et al., 2007), can probably be generalised to the older events. The summit of Piton de la Fournaise consequently presents an evolution similar to those of Etna and Masaya volcanoes, where pit craters recurrently collapse, each filled during subsequent summit eruptions (Rymer et al., 1998; Behncke et al., 2004; Harris, 2009).

Summit collapse structures of Piton de la Fournaise also have a wide range of geometries suggesting different collapse mechanisms. On the one hand, the 2007 Dolomieu caldera had steep inward walls and a flat floor during its initial stage of collapse (Michon et al., 2007), characteristics best explained by the collapse of a coherent rock column (Roche et al., 2000; Michon et al., 2009a). On the other hand, the smallest structures, as the 1964 Soufrière pit crater, had initially a surface width of $\sim 5 \mathrm{~m}$ and overhanging walls. The progressive collapse of the vault enlarged its surface dimension until the 2007 Dolomieu caldera collapse cut the structure. Such an evolution may result from the collapse of the roof of a cavity, which formed by non-coherent collapse of a rock column above a drained magma reservoir (Roche et al., 2001) or a zone of magma transfer (Okubo and Martel, 1998). An additional cause of pit crater collapse can be proposed for the small pit craters

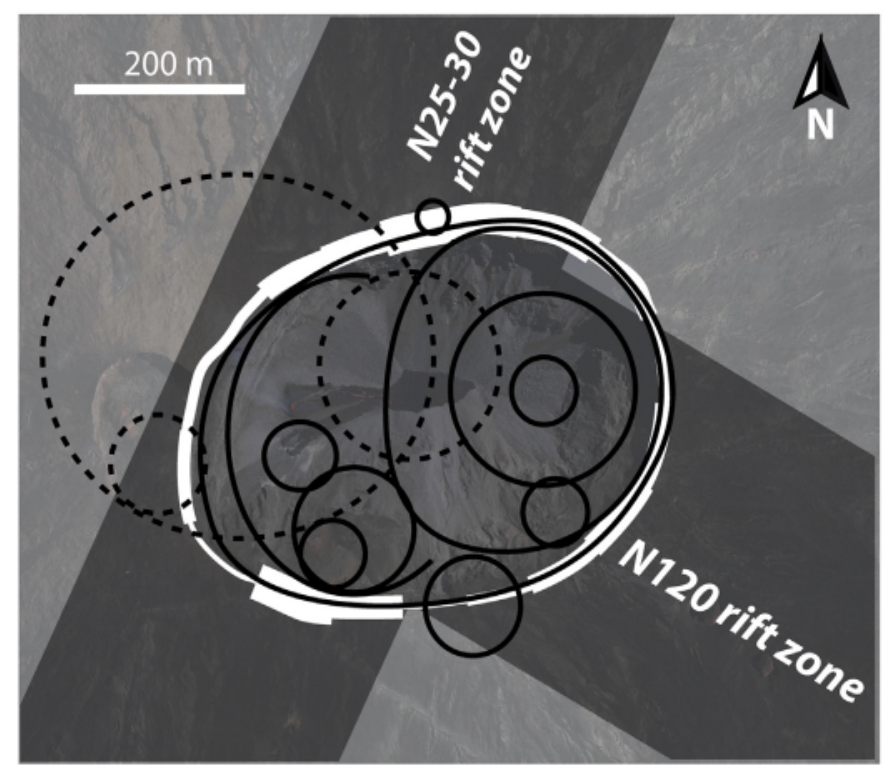

Fig. 12. Summit pit craters (black), rift zones and dike distribution (white) in the wall of the Dolomieu caldera (see text for explanation). Collapse structures related to recognised lateral eruptions are represented by thick black lines. Dashed lines denote pit craters for which a link to a lateral eruption is not established. Details on the age of each collapse structure are in Fig 4. 
that are scattered all around the summit area (Fig. 12). Their location can mimic that of old fragmental deposits (talus, scree, scoria cones or other) at shallow levels. Such deposits have lower coherence than lava flows, which could favour temporary magma storage at shallow levels, and can be easily assimilated or eroded away during lateral magma drainage as proposed by Okubo and Martel (1998) for pit craters along fault zones at Kîlauea. Most importantly, the fragmental (clastic) deposits permit the formation of small and vertically developed magma pockets (like the ones described in Peltier et al., 2012) prone to produce small pit craters.

\subsection{Origin and dynamics of explosive events}

Combining historical accounts, qualitative observations and deposit analysis, we tentatively identify two main types of summit explosive activity in historical times. Small explosions (Type 1) are characterised by discrete km-high ash and vapour pulses, and the ejection of minor fraction of lithic blocks in the vicinity of the source in the summit craters. These events are likely of phreatic origin, representing the dominant type of explosive eruption in the 20th and 21st centuries (Fig. 3), and are systematically associated with pit crater or caldera collapse. Interestingly, the magnitude of the explosions remains relatively modest despite the large range in diameter of collapse structures $(150 \mathrm{~m}$ in 1986 and $1 \mathrm{~km}$ in 2007).

Type 2 explosive eruptions occurred repeatedly during the 18th and 19th centuries, during or shortly after sustained summit effusive activity (Fig. 3). The only example in recent times (1961) is not associated with lateral, not summit, effusive activity. However, we cannot exclude the possibility that a shallow magma intrusion occurred and that its drainage resulted in the 1961 pit crater collapse. These explosive events show a wide range of dynamics bounded by two end-members.

The upper intensity end-member (Type 2a) is characterised by the development of a sustained vertical eruption column several kilometres high and likely has a phreatomagmatic origin (ex 1860; 1961). Historical records report ash falls related to these eruptions at distances of up to $50 \mathrm{~km}$ from the summit cone. Block ejection intensifies in the final phase of those eruptions, possibly marking an evolution toward phreatic dynamics associated with pit crater collapse.

Deposits related to the lower intensity end-member Type $2 b$ correspond to the blocks scattered on the ground north of Bory crater or within the "Black unit" spatter (U4) and attributed to the Mamelon Central activity. These eruptions were likely characterised by discrete but violent phreatic explosions with most ballistic blocks landing at significant distances from the source $(>1 \mathrm{~km})$.

We used the program EJECT! (v 1.3; Mastin, 2001), in which parameters such as the diameter, the density and the geometry of the blocks, their initial velocity, the ejection angle and the potential tailwind are computed, to calculate ballistic trajectories that are compatible with the current block distribution. Assuming a source in the Bory lava lake for the largest blocks (i.e. MD $>1 \mathrm{~m}$ at a maximum distance of $100 \mathrm{~m}$ around Bory), the block deposit may result from explosive events characterised by modest maximum initial velocities of $30-40 \mathrm{~m} \mathrm{~s}^{-1}$ (Fig. 13). The upper end-member of explosive eruptions corresponds to activity at the end of the 1860 eruption (Fig. 6b). Our calculations of the initial velocities for blocks of $0.6 \mathrm{~m}$ MD distributed around Dolomieu, 1-1.2 km from the source (i.e. Cratère Brûlant), would suggest ejection velocities up to about $100 \mathrm{~m} \mathrm{~s}^{-1}$ (Fig. 13). These values, related to the largest historical explosive event, are lower than those determined for the 1790 explosive events of Killauea (between 140 and $350 \mathrm{~m} \mathrm{~s}^{-1}$; Swanson et al., 2012a).

Conventionally, phreatic or phreatomagmatic explosions are interpreted to result from the interaction between hot rocks, magma and, most often, the water table (e.g. MacDonald, 1972). On basaltic volcanoes, this process may occur during (1) pit crater or caldera collapse (e.g., Geshi and Oikawa, 2008; Swanson et al.,

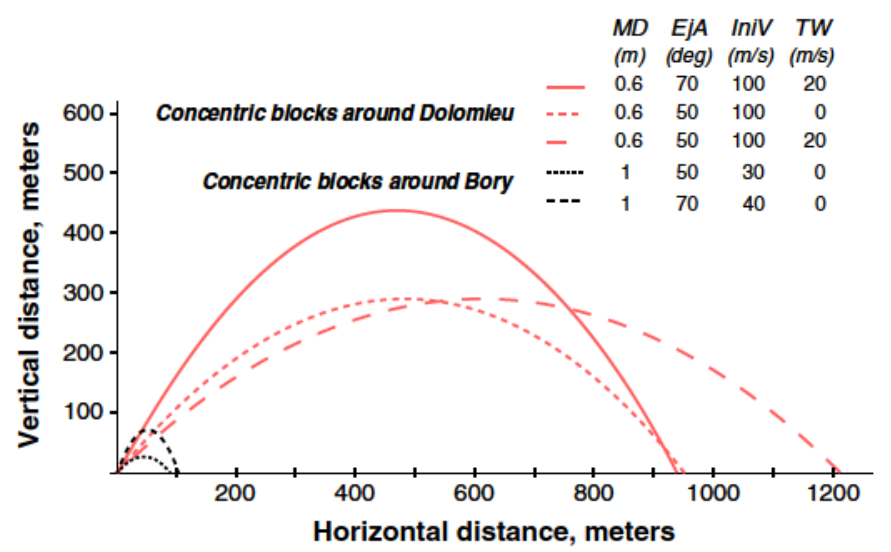

Fig. 13. Ballistic trajectories calculated with EJECT! ( 1 13; Mastin, 2001) for blocks that fell concentrically around Bory and Dolomieu. MD, EjA, IniV and TW correspond to mean diameter, ejection angle, initial velocity and tail wind, respectively.

2012b), or (2) after the draining of a lava lake (e.g., Jaggar and Finch, 1924; Decker and Christiansen, 1984). At Piton de la Fournaise, the top of the water table reaches $1800 \mathrm{~m}$ asl in the Enclos Fouqué, i.e. $600-700 \mathrm{~m}$ below the summit (Join et al., 2005). Contrary to Miyakejima, where collapse-related phreatomagmatic explosions propelled strongly altered materials (Geshi and Oikawa, 2008), or to Kīlauea, where gabbros were ejected during the 1790 explosions (Swanson et al., 2012a), the ballistic blocks spread over the summit craters of Piton de la Fournaise show no indication of major hydrothermal alteration despite the occurrence of a hydrothermal system 400-500 m deep below the summit (Lénat et al., 2000). This suggests that the phreatic and phreatomagmatic explosions described in the present work occurred at a very shallow level and thus do not result from the interaction between magma and the water table of hydrothermal fluids.

A review of recent (1985-2010) eruption-time distribution at Piton de la Fournaise points out that the frequency of volcanic events (eruptions or intrusions) is highest during the dry season (Roult et al., 2012). La Réunion and more specifically the Piton de la Fournaise volcano experience extreme rain events such as during the 2007 cyclone Gamède ( $4869 \mathrm{~mm}$ of precipitation on the volcano in 4 days). According to Barcelo (1996), 100\% of the rainfall infiltrated the Enclos Fouqué caldera, feeding a shallow temporary aquifer. As Type 2 explosive events were coeval with periods of sustained summit eruptive activity or occurrence of lava at shallow levels (e.g. the 1851-1860 lava lake), we propose that the development of such a temporary aquifer in periods of volcanic activity may have triggered phreatic to phreatomagmatic explosions. This interpretation is supported by the main March 1860 phreatomagmatic eruption, which was preceded by a large cyclone that induced severe floods on the island on February 25-26. However, we stress that this observation is far from being general, and it does not apply, for instance, to the 1961 event.

Type 1 explosive events are associated with pit crater collapse during lateral eruptions. However, pit crater collapses are not systematically associated with explosions, and their intensity remains in a very narrow range. The mechanism to develop these weak phreatic eruptions could be related to magma intrusion at very shallow levels below the summit. Interestingly, in March 1986 and April 2007, the collapse structures cut recent lava flows that were still partially molten (Delorme et al., 1989; Michon et al., 2007) and drained into the collapse structures, but this process did not produce ash pulses. Finally, the role of other, non-phreatic processes such as explosions due to rockfall that blocks gas escape (Houghton et al., 2011) or into a lava lake (Orr et al., 2013) is still unclear at Piton de la Fournaise, but cannot be excluded for explosions that occurred during the phases of sustained summit activity. 


\section{Conclusions}

We conclude from detailed analysis of i) historical records, ii) highresolution images of both the Dolomieu caldera walls and the surface of the summit cone, and iii) recent explosive eruptions and their deposits that:

1. The activity of Piton de la Fournaise recently evolved through two main successive periods. During the 18th and 19th centuries, eruptive activity was characterised by several sustained, longlasting effusive eruptions associated with frequent phreatic explosions and ended with phreatomagmatic explosions. In contrast, the 20th and 21st centuries were marked mostly by discrete effusive activity coeval with minor phreatic explosions during pit crater collapses, which were triggered by lateral eruptions.

2. The Central Cone built quite rapidly during a recent phase of sustained activity, essentially centred on the western summit crater (Bory). Since the late 19th century, its growth has drastically slackened, and the summit has been mostly affected by pit crater or caldera collapses centred on the eastern crater (Dolomieu).

3. The most violent summit explosions are phreatomagmatic and result from the interaction between magma and shallow water, i.e. fluids located above the permanent water table and the hydrothermal system. Several scenarios then exist, depending on the type of volcanic activity (sustained or short-lived eruptions, summit collapses) and the input of water by rain infiltration.

4. Pit crater and caldera collapses result from magma draining during lateral eruptions. We propose that shallow magma storage develops in fragmental deposits, such as talus, screes and pyoclastic cones, and its subsequent draining is a likely mechanism to explain the development of small pit craters such as those of 1953, 1961, 1986 and 2002 .

\section{Acknowledgments}

Funding by the French "Ministère de l'Ecologie, de l'Energie, du Développement durable et de la Mer" and the Remote Sensing program of the University of La Réunion is gratefully acknowledged. The authors warmly thank P. Bachèlery for constructive discussions and N. Metrich and V. Famin for an early internal review of the manuscript. The manuscript greatly benefited from the thorough review of D.A. Swanson. IPGP contribution 3409.

\section{References}

Bachèlery, P., 1981. Le Piton de la Fournaise (Ile de la Réunion). Etude volcanologique, structurale et pétrologique.University of Clermont-Ferrand, Clermont-Ferrand (Ph.D. thesis).

Barœlo, A., 1996. Analyse des mêcanismes hydrologiques en domaine volcanique insulaire à relief jeune. Apports à la connaissance du bilan hydrique. Massif du Piton de la Fournaise (île de la Réunion). Université de Montpellier II, Montpellier (Ph.D. thesis, 266 pp.).

Battaglia, J., Ferrazzini, V., Staudacher, T, Aki, K, Cheminée, J.-L, 2005. Pre-eruptive migration of earthquakes at the Piton de la Fournaise volcano (Réunion island). Geophysical Journal International 161, 549-558. http://dx.doi.org/10.1111/j.1365246X.2005.02606.x.

Behncke, B, Neri, M., Sturiale, G., 2004. Rapid morphological changes at the summit of an active volcano: reappraisal of the poorly documented 1964 eruption of Mount Etna (Italy). Geomorphology 63, 203-218. http://dx.doi.org/10.1016/j.geomorph.2004.04.004.

Bory de Saint Vincent, JB.G., 1804. Voyage dans les quatre principales iles des mers d'Afrique, fait par ordre du gouvernement, pendant les années neuf et dix de la République (1801 et 1802). Buisson, Paris (4 volumes).

Bureau, H., Métrich, N., Pineau, F., Semet, M.P., 1998. Magma-conduit interaction at Piton de la Fournaise volcano (Réunion Island): a melt and fluid inclusion study. Journal of Volcanology and Geothermal Research 84, 39-60.

Bureau, H., Métrich, N., Semet, M.P., Staudacher, T., 1999. Fluid-magma decoupling in a hot-spot volcano. Geophysical Research Letters 26, 3501-3504.

Carter, A., van Wyk de Vries, B., Kelfoun, K., Bachèlery, P., Briole, P., 2007. Pits, rifts and slumps: the summit structure of Piton de la Fournaise. Bulletin of Volcanology 69, 741-756. http://dx.doi.org/10.1007/s00445-006-0103-4.

de Crémont, $\mathrm{H}$., 1770. Lettre IV, Relation du premier voyage fait au volcan de l'isle Bourbon. In: Fréron, E.-C (Ed.), L'année littéraire, 7. Delalain, Paris, pp. 73-97. de Montessus, F.-B, 1889. Martyrologe et biographie de Commerson, médecin botaniste et naturaliste du roi, médecin de Toulon-sur-Arroux (Saône-et-Loire) au XVIIIe siècle. L. Marceau, Chalon sur Saône (225 pp.).

Decker, R.W., Christiansen, R.L, 1984. Explosive eruptions of Kilauea Volcano, Hawaii. Explosive volcanism: inception, evolution and hazards. National Research Council, National Academy Press, Washington, pp. 122-132.

Delorme, H., Bachèlery, P., Blum, P.A. Cheminée, J.L., Delarue, J.F., Delmond, J.C., Hirn, A. Lépine, J.C. Vincent, P.M., Zlotnicki, J, 1989. March 1986 eruptive episodes at Piton de la Fournaise volcano (Réunion Island). Journal of Volcanology and Geothermal Research 36, 199-208.

d'Heguerty, P.A, 1755. Observations sur le volcan de l'isle Bourbon. Mémoires de la Société Royale des Sciences et Belles Lettres de Nancy, Antoine, Nancy, 3, pp. 218-235.

Ducrot, M., 1958. Le volcan de La Réunion (période 1952-1957). Travaux du Bureau Géologique, 88. Service Géologique de Tananarive (95pp.).

Geshi, N , Oikawa, T, 2008. Phreatomagmatic eruptions associated with the caldera collapse during the Miyakejima 2000 eruption, Japan. Journal of Volcanology and Geothermal Research 176, 457-468. http://dx.doi.org/10.1016/j.jvolgeores.2008.04.013.

Harris, A.J.L, 2009. The pit-craters and pit-crater-filling lavas of Masaya volcano. Bulletin of Volcanology 71, 541-558. http://dx.doi.org/10.1007/s00445-008-0241-y.

Heliker, C., Kauahikaua, J, Sherrod, D.R., Lisowski, M, Cervelli, P.F., 2003. The rise and fall of Pu'u 'Ō'ō cone, 1983-2002. In: Heliker, C., Swanson, D.A., Takahashi, T.J. (Eds.), The Pu'u 'Ō'ō-Kupaianaha Eruption of Killauea Volcano, Hawai'i: The first 20 Years. USGS Professional Paper 1676, pp. 28-51.

Hirn, A., Lepine, J., Sapin, M., Delorme, H., 1991. Episodes of pit-crater collapse documented by seismology at Piton de la Fournaise. Journal of Volcanology and Geothermal Research 47, 89-104.

Houghton, B.F., Swanson, D.A., Carey, R.J., Rausch, J. Sutton, A.J., 2011. Pigeonholing pyroclasts: insights from the 19 March 2008 explosive eruption of Kilauea volcano. Geology 39, 263-266. http://dx. doi.org/10.1130/G31509.1.

Hugoulin, F., 1860. Dernière éruption du volcan de l'île de la Réunion (19 mars 1860). Revue Algérienne et Coloniale 2, 483-487.

Jaggar, T.A., Finch, R.H., 1924. The explosive eruption of Kilauea in Hawaii, 1924. American Journal of Science 8, 353-374.

Join, J.-L., Folio, J.-L, Robineau, B., 2005. Aquifers and groundwater within active shield volcanoes. Evolution of conceptual models in the Piton de la Fournaise volcano. Journal of Volcanology and Geothermal Research 147, 187-201. http://dx.doi.org/ 10.1016/j.jvolgeores.2005.03.013.

Lacroix, A, 1925. Succession des éruptions et bibliographie du volcan actif de la Réunion. Bulletin of Volcanology 3-4, 20-56.

Lacroix, A, 1936. Le volcan actif de lîle de la Réunion et ses produits. Gauthier-Villars, Paris (297 pp.).

Lénat, J.-F., Bachèlery, P., 1990. Structure and dynamics of the central zone of Piton de la Fournaise volcano. In: Lénat, J.-F. (Ed.), Le Volcanisme de la Réunion, Monographie. Centre De Recherche Volcanologique, Clermont-Ferrand, pp. 257-296.

Lénat, J., Fitterman, D, Jackson, D., Labazuy, P., 2000. Geoelectrical structure of the central zone of Piton de la Fournaise volcano (Réunion). Bulletin of Volcanology 62, 75-89.

Lénat, J.-F., Bachèlery, P., Desmulier, F., 2001. Genèse du champ de lave de l'Enclos Fouqué: une eruption d'envergure exceptionnelle au Piton de la Fournaise (Réunion) au 18ème siècle. Bulletin de la Société Géologique de France 172,177-188.

Longpré, M.-A., Staudacher, T., Stix, J, 2007. The November 2002 eruption at Piton de la Fournaise volcano, La Réunion Island: ground deformation, seismicity, and pit crater collapse. Bulletin of Volcanology 69, 511-525. http://dx,doi.org/10.1007/s00445-006 0087-0.

MacDonald, G.A., 1972. Volcanoes. Prentice-Hall, Inc., Englewood Cliffs, New Jersey (510 pp.).

Maillard, L, 1853. Note sur l'île de la Réunion. Bulletin de la Société Géologique de France $10,499-505$.

Maillard, L, 1862. Notes sur lîle de la Réunion (Bourbon). Lanée, Paris (344pp.).

Massin, F, Ferrazzini, V, Bachèlery, P., Nercessian, A, Duputel, Z, Staudacher, T, 2011. Structures and evolution of the plumbing system of Piton de la Fournaise volcano inferred from clustering of 2007 eruptive cyde seismicity. Journal of Volcanology and Geothermal Research 202, 96-106. http://dx.doi.org/10.1016/j.jvolgeores.2011.01.008.

Mastin, LG., 2001. EJECT! A program for the calculation of ballistic trajectories of volcanic blocks. U.S. Geological Survey Open-File Report, 01-45 (13 pp.).

Michon, L., Staudacher, T., Ferrazzini, V., Bachèlery, P., Martí, J. 2007. April 2007 collapse of Piton de la Fournaise: a new example of caldera formation. Geophysical Research Letters 34, L21301. http://dx.doi.org/10.1029/2007GL031248.

Michon, L, Villeneuve, N., Catry, Th., Merle, O, 2009a. How summit calderas collapse on basaltic volcanoes: new insights from the April 2007 caldera collapse of Piton de la Fournaise volcano. Journal of Volcanology and Geothermal Research 184, 138-151. http://dx.doi.org/10.1016/j.jvolgeores.2008.11.003.

Michon, L, Cayol, V., Letourneur, L., Peltier, A., Villeneuve, N., Staudacher, Th, 2009b. Edifice growth ${ }_{i}$ deformation and rift zone development in basaltic setting: insights from Piton de la Fournaise shield volcano (Réunion Island, Indian Ocean). Journal of Volcanology and Geothermal Research 184, 14-30. http://dx.doi.org/10.1016/ j.jvolgeores.2008.11.002.

Nercessian, A, Hirn, A, Lépine, J.-C., Sapin, M, 1996. Internal structure of Piton de la Fournaise volcano from seismic wave propagation and earthquake distribution. Journal of Volcanology and Geothermal Research 70, 123-143.

Okubo, C.H., Martel, S.J., 1998. Pit crater formation on Kilauea volcano, Hawaii. Journal of Volcanology and Geothermal Research 86, 1-18.

Orr, T.R., Thelen, W.A., Patrick, M.R., Swanson, D.A., Wilson, D.C., 2013. Explosive eruptions triggered by rockfalls at Killauea volcano, Hawai'i. Geology 41, 207-210. http://dx.doi.org/10.1130/G33564.1.

Peltier, A, Ferrazzini, V., Staudacher, T., Bachèlery, P., 2005. Imaging the dynamics of dyke propagation prior to the 2000-2003 flankeruptions at Piton de La Fournaise, Reunion Island. Geophysical Research Letters 32, L22302. http://dx.doi.org/10.1029/2005GL023720. 
Peltier, A., Massin, F., Bachèlery, P., Finizola, A., 2012. Internal structure and building of basaltic shield volcanoes: the example of the Piton de la Fournaise terminal cone (La Réunion). Bulletin of Volcanology 74, 1881-1897.

Roche, O., Druitt, T., Merle, 0, 2000. Experimental study of caldera formation. Journal of Geophysical Research 105, 395-416.

Roche, 0 ., van Wyk de Vries, B, Druitt, T, 2001. Sub-surface structures and collapse mechanisms of summit pit craters. Journal of Volcanology and Geothermal Research 105, 1-18.

Roult G Peltier, A, Taisne, B, Staudacher, Th, Ferrazzini, V, Di Muro, A the OVPF team, 2012. A new comprehensive classification of the Piton de la Fournaise activity spanning the 1985-2010 period. Search and analysis of short-term precursors from broad-band seismological station. Journal of Volcanology and Geothermal Research 241-242, 78-104.

Rymer, H, van Wyk de Vries, B., Stix, J., Williams-Jones, G., 1998. Pit crater structure and processes governing persistent activity at Masaya Volcano, Nicaragua. Bulletin of Volcanology 59, 345-355.

Staudacher, Th., Ferrazzini, V., Peltier, A., Kowalski, P., Boissier, P., Catherine, P., Lauret, F. Massin, F., 2009. The April 2007 eruption and the Dolomieu crater collapse, two major events at Piton de la Fournaise (La Réunion Island, Indian Ocean). Journal of Volcanology and Geothermal Research 184, 126-137. http://dx.doi.org/10.1016/ j.jvolgeores.2008.11.005.
Swanson, D.A, Rose, T.R., Fiske, R.S., McGeehin, J.P., 2012b. Keanakăko'i Tephra produced by 300 years of explosive eruptions following collapse of Kīlauea's caldera in about 1500CE. Journal of Volcanology and Geothermal Research 215-216, 8-25. http:// dx.doi.org/10.1016/j.jvolgeores.2011.11.009.

Swanson, D.A., Zolkos, S.C., Haravitch, B., 2012a. Ballistic blodks around Kilauea Caldera: their vent locations and number of eruptions in the late 18th century. Journal of Volcanology and Geothermal Research 231-232, 1-11.

Tanguy, J-C Bachèlery, P LeGoff, M, 2011. Archeomagnetism of Piton de la Fournaise: bearing on volcanic activity at La Réunion Island and geomagnetic secular variation in Southern Indian Ocean. Earth and Planetary Science Letters 303, 361-368. http:// dx.doi.org/10.1016/j.epsl.2011.01.019.

Toutain, J.P., Bachèlery, P., Blum, P.A., Cheminée, J.-L., Delorme, H., Fontaine, L. Kowalski, Ph., Taochy, Ph., 1992. Real time monitoring of vertical ground deformations during eruptions at Piton de la Fournaise. Geophysical Research Letters 19, 553-556. http://dx.doi.org/10.1029/91GL00438.

Velain, Ch, 1878. Description géologique de la presqu'ile d'Aden, de l'ile de la Réunion, des iles Saint-Paul et Amsterdam. Hennuyer, Paris (356 pp.).

Villeneuve, N., Bachèlery, P., 2006. Revue de la typologie des éruptions au Piton de La Fournaise, processus et risques volcaniques associés. Cybergeo: European Journal of Geography (http://cybergeo.revues.org/2536). 